\title{
MAGNETOSOME FORMATION IN PROKARYOTES
}

\author{
Dennis A. Bazylinski and Richard B. Frankel \\ Magnetotactic bacteria were discovered almost 30 years ago, and for many years and many \\ different reasons, the number of researchers working in this field was few and progress was slow. \\ Recently, however, thanks to the isolation of new strains and the development of new techniques \\ for manipulating these strains, researchers from several laboratories have made significant \\ progress in elucidating the molecular, biochemical, chemical and genetic bases of magnetosome \\ formation and understanding how these unique intracellular organelles function. We focus here \\ on this progress.
}

Magnetotactic bacteria ${ }^{1}$ are motile, mostly aquatic prokaryotes that swim along geomagnetic field lines. Some types of magnetotactic bacteria in water droplets swim persistently northwards in the northern hemisphere; this observation led to their serendipitous discovery by R. P. Blakemore, then a graduate student at the University of Massachusetts at Amherst. All magnetotactic bacteria synthesize unique intracellular structures called magnetosomes ${ }^{2}$, which comprise a magnetic mineral crystal surrounded by a lipid bilayer membrane about 3-4 nm thick. In general, little is known about the methods by which bacteria synthesize these mineral crystals, although there has been a good deal of progress both in the isolation and mass-culturing of these microorganisms, and in our understanding of some of the specific features of magnetosomes and how they function within cells. We review this progress in this article, focusing mainly on the synthesis of the bacterial magnetosome.

\section{The magnetotactic bacteria}

The term 'magnetotactic bacteria' has no taxonomic significance and represents a heterogeneous group of FASTIDIOUS PROKARYOTES that display a myriad of cellular morphologies, including coccoid, rod-shaped, VIBRIOID, spirilloid (helical) and even multicellular ${ }^{3,4}$. They represent a collection of diverse bacteria that possess the widely distributed trait of magnetotaxis ${ }^{3}$ - the term that is used to describe their magnetic behaviour.
Despite the great diversity of these microorganisms, they have several important features in common ${ }^{4}$ : all that have been described are Gram-negative members of the domain Bacteria; they are all motile, generally by flagella; all exhibit a negative TACTIC and/or growth response to atmospheric concentrations of oxygen; all strains in pure culture have a respiratory form of metabolism (that is, none are known to ferment substrates); and they all possess magnetosomes (FIG. 1). It is possible that some Archaea or non-motile bacteria produce magnetosomes; however, none have been reported so far.

Magnetotactic bacteria are easy to detect in samples collected from natural habitats without isolation and cultivation $^{5}$. They are cosmopolitan in distribution but, on a local basis, they are found in their highest numbers at, or just below, the OXIC-ANOXIC INTERFACE in aquatic habitats, where they can constitute a significant proportion of the bacterial population ${ }^{4,6}$. Physiological studies of several strains of magnetotactic bacteria show that they have the potential to participate in the biogeochemical cycling of several important elements, including iron, nitrogen ${ }^{7-10}$, sulphur ${ }^{11-15}$ and carbon $^{11}$, in natural environments.

The sensitivity of most magnetotactic bacteria to even relatively low concentrations of oxygen (they are OBLIGATE MICROAEROPHILES, anaerobes or both) and the fact that cells of most cultivated strains only produce magnetosomes in a narrow range of very low oxygen 


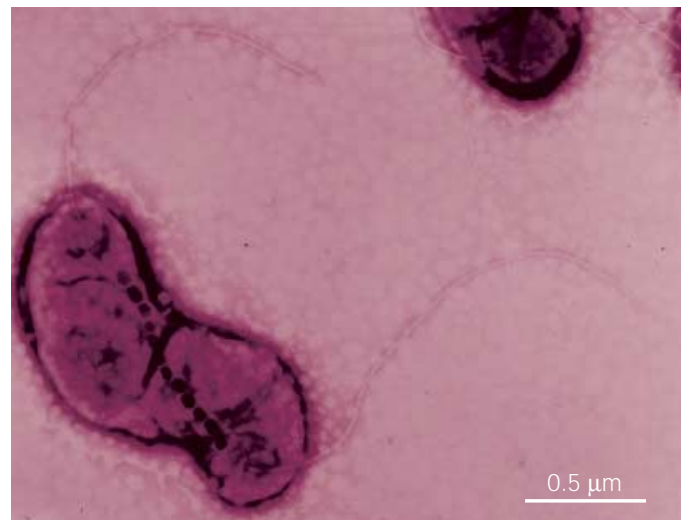

Figure 1 | Transmission electron micrograph of a negatively stained cell of a typical magnetotactic bacterium. This is a cell of strain MV-4, a marine magnetotactic spirillum. It has a flagellum at each end of the cell and a chain of electron-dense, magnetite-containing magnetosomes along the long axis of the cell.

concentrations were probably the primary limiting factors in this field of research for many years. Even now, there are relatively few species available in pure culture and even fewer working genetic systems in these organisms.

\section{Bacterial magnetosome mineral crystals}

Overall, magnetosome crystals have high chemical purity, narrow sizeranges, species-specific crystal morphologies and exhibit specific arrangements within the cell ${ }^{4,6,11}$. These features indicate that the formation of magnetosomes by magnetotactic bacteriais under precise biological control and is mediated by a mineralization process, which is known as biologically controlled mineralization ${ }^{16}$.

M agnetotactic bacteria usually mineralize either iron oxide magnetosomes, which contain crystals of magnetite $\left(\mathrm{Fe}_{3} \mathrm{O}_{4}\right)^{17}$, or iron sulphide magnetosomes, which contain crystals of greigite $\left(\mathrm{Fe}_{3} \mathrm{~S}_{4}\right)^{14,15,18}$. Several other iron sulphideminerals have also been identified in iron sulphide magnetosomes - including mackinawite (tetragonal FeS) and a cubic FeS - which arethought to be precursors of $\mathrm{Fe}_{3} \mathrm{~S}_{4}{ }^{19,20}$. One organism is known to produce both iron oxide and iron sulphidemagnetosomes $^{21,22}$, but has not yet been isolated and grown in pure culture. The mineral composition of the magnetosome seems to be under strict chemical control, because even when hydrogen sulphide is present in the growth medium, cells of several cultured magnetotactic bacteria continueto synthesize $\mathrm{Fe}_{3} \mathrm{O}_{4}$ and not $\mathrm{Fe}_{3} \mathrm{~S}_{4}^{23,24}$. $\mathrm{M}$ oreover, $\mathrm{Fe}_{3} \mathrm{O}_{4}$ crystals in magnetosomes are of high chemical purity ${ }^{4,6,11}$, and reports of impurities, such as other metal ions, within the crystals are rare ${ }^{25}$. Additionally, no proteins are found within $\mathrm{Fe}_{3} \mathrm{O}_{4}$ magnetosome crystals ${ }^{26}$.

Phylogenetic analysis of many cultured and uncultured magnetotactic bacteria shows that most of the $\mathrm{Fe}_{3} \mathrm{O}_{4}$-producing strains are associated with the $\alpha$-subdivision of the PROTEOBACTERIA ${ }^{6,11}$, whereas one uncultured $\mathrm{Fe}_{3} \mathrm{~S}_{4}$-producing bacterium is associated with the sulphate-reducing bacteria in the $\delta$-subdivision of the Proteobacteria ${ }^{27}$. Asthe different subdivisions of the Proteobacteria are considered to be coherent, distinct evolutionary lines of descent ${ }^{28,29}$, D eLong et al. ${ }^{27}$ proposed that the evolutionary origin of magnetotaxis was polyphyletic and that magnetotaxis that is based on iron oxide magnetosomes evolved separately from that based on iron sulphide magnetosomes. However, recent studies have shown that not all magnetotactic bacteria with $\mathrm{Fe}_{3} \mathrm{O}_{4}$ magnetosomes are associated with the $\alpha$-Proteobacteria. D esulfovibrio magneticus strain RS-1 (REF. 13), which is a cultured, sulphate-reducing magnetotactic bacterium, has $\mathrm{Fe}_{3} \mathrm{O}_{4}$ magnetosomes, yet belongs to the $\delta$-Proteobacteri $a^{30}$, whereas another uncultured magnetotactic bacterium with $\mathrm{Fe}_{3} \mathrm{O}_{4}$ magnetosomes, M agnetobacterium bavaricum ${ }^{31}$, is placed phylogenetically within the Bacteria in the newly formed Nitrospira phylum, not in the Proteobacteria ${ }^{6}$. These results indicate that magnetotaxis as a trait might have evolved several times and, moreover, could indicate that thereis morethan one biochemical/chemical pathway for the biomineralization of magnetic minerals by magnetotactic bacteria. Alternatively, these findings might also beexplained by thelateral transfer of a group or groups of genes that are responsiblefor magnetosome synthesis between diverse microorganisms.

The particle morphology of $\mathrm{Fe}_{3} \mathrm{O}_{4}$ and $\mathrm{Fe}_{3} \mathrm{~S}_{4}$ magnetosome crystals varies, but is consistent within cells of a single magnetotactic bacterial species or strain ${ }^{32}$. Three general crystal morphologies have been reported in magnetotactic bacteria on the basis of their two-dimensional projections in the electron microscope: roughly cuboidal2,3,32,33; elongated prismatic (roughly rectangular) 3,5,23-25,32; and tooth-, bullet- or arrowhead-shaped ${ }^{34-36}$ (BOX 1; FIG. 2).

$\mathrm{M}$ agnetosome $\mathrm{Fe}_{3} \mathrm{O}_{4}$ and $\mathrm{Fe}_{3} \mathrm{~S}_{4}$ crystals are typically 35- $120 \mathrm{~nm}$ long ${ }^{32}$. This size range is within the permanent, single-magnetic-domain (SD) size range ${ }^{37,38}$ for both minerals. Smaller crystals are superparamagnetic, that is, not permanently magnetic at ambient temperature, and domain walls would form in larger crystals. In both cases, the M AGNETIC REM ANENCE is less than that of SD crystals. Statistical analyses of crystal size distributions in cultured strains show narrow, asymmetrical distributions and consistent width-to-length ratios within each strain $^{39}$. Whereas the size distributions of inorganic $\mathrm{Fe}_{3} \mathrm{O}_{4}$ crystals are typically log-normal tailing out to large crystal sizes ${ }^{40}$, the size distributions of magnetosome $\mathrm{Fe}_{3} \mathrm{O}_{4}$ crystals have a sharp, high-end cutoff within the SD sizerange $\mathrm{e}^{39}$.

\section{Magnetotaxis}

In most magnetotactic bacteria, the magnetosomes are arranged in oneor morechain $s^{4,41}$. Magnetic interactions between themagnetosome crystalsin a chain cause their MAGNETIC DIPOLE MOMENTS to orientate parallel to each other along the length of the chain. In this chain arrangement, thetotal magnetic dipolemoment of the cell is the sum of the permanent magnetic dipole moments of theindividual SD magnetosome particles. $M$ agnetic measurements ${ }^{42}$, magnetic force microscopy ${ }^{43}$ 
Box 1 | Magnetosome crystal morphology

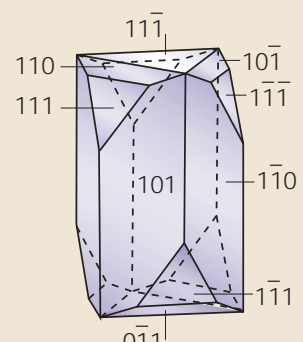

$\{110\}+\{111\}$

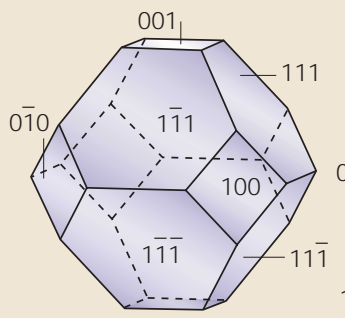

Cuboctahedron $\{100\}+\{111\}$

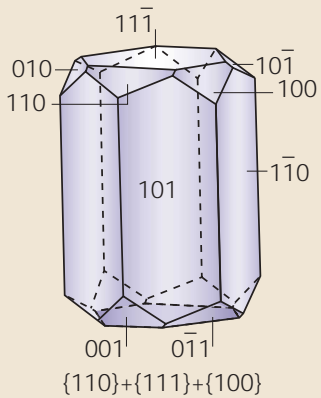

$\{110\}+\{111\}+\{100\}$

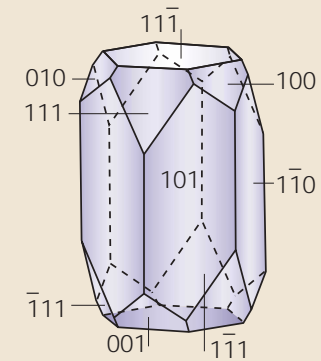

$\{110\}+\{111\}+\{100\}$

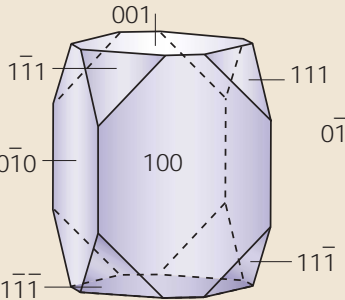

Elongated $\{100\}+\{111\}$

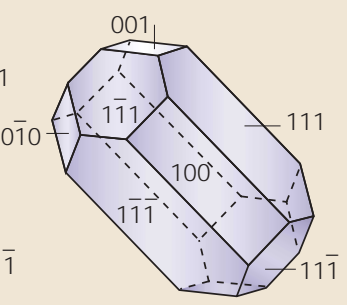

Elongated $\{100\}+\{111\}$
$\mathrm{Fe}_{3} \mathrm{O}_{4}$ and $\mathrm{Fe}_{3} \mathrm{~S}_{4}$ haveface-centred, spinel crystal structures ( $\mathrm{Fd} 3 \mathrm{~m}$ space group) ${ }^{114}$. Idealized crystal habits, derived from high-resolution electron microscopy studies, are based on combinations of $\{100\}$ (cube), $\{110\}$ (dodecahedron) and $\{111\}$ (octahedron) forms (bracketed numbers represent specific crystal forms) ${ }^{114}$. Macroscopic crystals of $\mathrm{Fe}_{3} \mathrm{O}_{4}$ often display habits of the octahedral $\{111\}$ form, and, more rarely, of the dodecahedral $\{110\}$ or cubic $\{100\}$ forms. The idealized habits of cuboidal magnetosome crystals are cuboctahedra, composed of $\{100\}+\{111\}$ form $\mathrm{s}^{33}$, with equal development of the six symmetry-related faces of the $\{100\}$ form and the eight symmetry-related faces of the $\{111\}$ form. The habits of thenon-equidimensional crystals that are found in some magnetotactic strains can be described as combinations of $\{100\},\{111\}$ and $\{110\}$ form $\mathrm{s}^{39}$. In these cases, as shown in the figure, the six, eight and 12 symmetry-related faces of the respective forms that constitute the habits do not develop equally. With the exception of the equidimensional cuboctahedron in the lower left panel of the figure, all the crystal habits shown have elongated projected shapes, which could result from ANISOTROPY during crystal growth. Anisotropy could derivefrom an anisotropic flux of ions through the magnetosomemembrane surrounding the crystal, or from anisotropic interactions of the magnetosome membrane with the growing crystal ${ }^{82}$. In these cases, the growth process could break the symmetry of the faces of each form.

The most anisotropic crystal habits are those of the tooth-, bullet- or arrowheadshaped $\mathrm{Fe}_{3} \mathrm{O}_{4}$ crystals (FIG. 2). Growth of these crystals seems to occur in two stages. The nascent crystals are cuboctahedra, which subsequently elongate along a [111] axis to form a pseudo-octahedral prism with alternating (110) and (100) faces, capped by (111) faces ${ }^{34,35}$. Tooth-shaped $\mathrm{Fe}_{3} \mathrm{~S}_{4}$ crystals havealso been observed ${ }^{20}$.

Elongated crystals are so unusual that their presence in recent and ancient sediments and in the Martian meteoriteALH 84001 has led to their designation as magnetofossils ${ }^{115}$, and is cited as evidence for the past presence of magnetotactic bacteria in aquatic habitats and sediments ${ }^{115-117}$ and life on ancient Mars ${ }^{118-121}$. However, elongated crystals of $\mathrm{Fe}_{3} \mathrm{O}_{4}$ have recently been synthesized in the laboratory ${ }^{122}$. Figure modified with permission from REF. $39 \odot$ (1998) Mineralogical Society of America.

and ELECTRON HOLOGRAPHY ${ }^{44}$ (FIG. 3) studies confirm this conclusion, and show that the chain of magnetosomes in a magnetotactic bacterium functions as a single magnetic dipole. The cell has therefore maximized its magnetic dipole moment by arranging the magnetosomes in chains. The magnetic dipole moment of the cell is usually large enough such that itsinteraction with the Earth's geomagnetic field overcomes the thermal forces that tend to randomize the orientation of the cell in its aqueous surroundings ${ }^{45}$. Magnetotaxis results from the passive alignment of the cell al ong geomagnetic field lines while it swims. Cells are neither attracted nor pulled towards either geomagnetic pole. Dead cells also align along geomagnetic field lines but do not move. So, these living cells behave like tiny, self-propelled magnetic compass needles.

The term magnetotaxis, which has been used to describethe behaviour of magnetotactic bacteria, is in fact a misnomer. In contrast to a true tactic response, magnetotactic cells swim neither up nor down a magnetic field gradient. In water droplets, cells of each magnetotactic species or strain display either 'two-way' or 'one-way' swimming behaviour along local geomagnetic field lines. In the two-way swimming mode, which is exemplified by M agnetospirillum spp. grown in liquid culture, cells are equally likely to swim parallel and anti-parallel to the magnetic field with random abrupt changes in direction ${ }^{46}$ (see online M ovie 1 ). In theone-way swimming mode, which is typified by the marine coccus, strain M C-1, cells swim persistently in one direction along the magnetic field and accumulate on one side of a water droplet ${ }^{46}$.

Bacteria from northern-hemisphere sites swim preferentially parallel to the magnetic field, which corresponds to a northward migration in the geomagnetic field; these bacteria are known as north-seeking (NS) ${ }^{1}$. Bacteria from southern-hemisphere sites swim preferentially anti-parallel to the magnetic field and are known as south-seeking (SS) ${ }^{47}$ (FIG. 4a). The geomagnetic field is inclined downwards from the horizontal in the northern hemisphere and upwards in the southern hemisphere, with the magnitude of the inclination increasing from the equator to the poles. N S cells in the northern hemisphere and SS cells in the southern hemisphere therefore migrate downwards towards the sediments along the inclined geomagnetic field lines. Theoriginal hypothesis was that magnetotaxis helps to guide cells downwards to less-oxygenated regions of the habitat (the sediment), where they would presumably stop swimming and adhere to sediment particles. If displaced from the sediments up into the water column, they would use the magnetic field to migrate back down ${ }^{1,3}$. This theory is consistent with thepredominant occurrence of NS cells in the northern hemisphereand SS cells in the southern hemisphere.

The discovery of large populations of magnetotactic bacteria at the oxic-anoxic interface in water columns of chemically stratified, aquatic habitats ${ }^{22}$, and the isolation of obligately microaerophilic, coccoid magnetotactic bacterial strain $\mathrm{s}^{47}$, have led us to revise our view of magnetotaxis. The original model did not completely explain how bacteria in the anoxic zone of a water column ben efit from magnetotaxis, nor did it explain how magnetotactic cocci form microaerophilic bands of cells in semi-solid, oxygen-gradient growth media. Experiments involving various strains of magnetotactic bacteria with $\mathrm{Fe}_{3} \mathrm{O}_{4}$ magnetosomes in oxygen-concentration gradients in thin, flattened capillary tubes showed clearly that magnetotaxis and AEROTAXIs work in conjunction in 
a

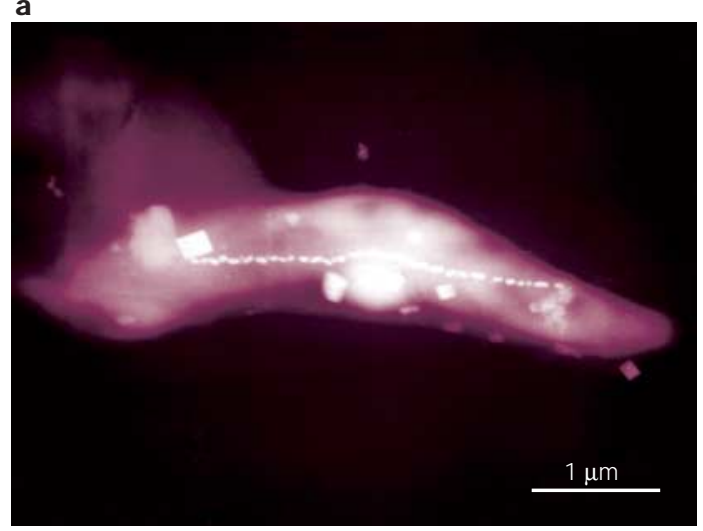

b

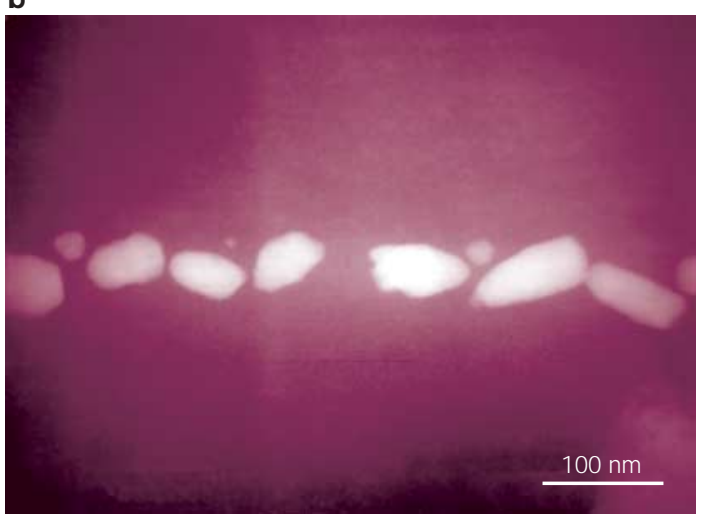

Figure 2 | Anisotropic crystal habits of $\mathbf{F e}_{3} \mathbf{O}_{4}$ crystals. a | Dark-field scanning-transmission electron microscope (STEM) image of an uncultured spirilum collected from the Pettaquamscutt Estuary, Rhode Island, USA, containing a chain of tooth-shaped magnetite crystals that traverse the cell along its long axis. $\mathbf{b}$ |High-magnification STEM image of the crystals from the cell in part $\mathbf{a}$.

these bacteria ${ }^{47}$. Aerotaxis is the response by which bacteria migrate to an optimal oxygen concentration in an oxygen gradient ${ }^{48}$. It has been shown that, in water droplets, one-way swimming magnetotactic bacteria can reverse their swimming direction and swim backwards under reducing conditions (less than optimal oxygen concentration), as opposed to oxic conditions (greater than optimal oxygen concentration). The behaviour that has been observed in these bacterial strains has been referred to as 'magneto-aerotaxis' ${ }^{47}$.

Two different magneto-aerotactic mechanismsknown as polar and axial - are found in different magnetotactic bacterial strain $s^{47}$ (FIG. 4b). Somestrains that swim persistently in one direction along the magnetic field (NS or SS) - mainly the magnetotactic cocci - are polar magneto-aerotactic. Those that swim in either direction along magnetic field lines with frequent, spontaneous reversals of swimming direction without turning around - for example, freshwater spirilla - are axial magneto-aerotactic and the distinction between NS and SS does not apply to these bacteria (see online M ovie 2). The magnetic field provides both an axis and a direction of motility for polar magneto-aerotactic bacteria, whereas it only provides an axis of motility for axial types of bacteria. In both cases, magnetotaxis increases the efficiency of aerotaxis in vertical concentration gradients by reducing a three-dimensional search to a single dimension ${ }^{47}$. It is possible, and perhaps likely (given that greigite producers al so seem to occupy discrete depths in the anaerobic zone of chemically stratified ponds), that there are other forms of magnetically assisted chemotaxis in response to molecules or ions other than oxygen, such as sulphide, or magnetically assisted redox- or phototaxis in bacteria that inhabit the anaerobic zone below the oxic-anoxic interface.

\section{Conditions that favour magnetosome synthesis}

As there are no strains of magnetotactic bacteria with $\mathrm{Fe}_{3} \mathrm{~S}_{4}$ magnetosomes in pure culture, very little is known about how, and under what conditions, these organisms synthesize $\mathrm{Fe}_{3} \mathrm{~S}_{4}$. However, given the anaerobic, sulphidic conditions of the sites at which they are generally found ${ }^{49-52}$, it is likely that $\mathrm{Fe}_{3} \mathrm{~S}_{4}$ mineralization by magnetotactic bacteria occurs only in the absence of oxygen.

Several factors influence $\mathrm{Fe}_{3} \mathrm{O}_{4}$ magnetosome biomineralization, the most important being oxygen concentration and the presence of nitrogen oxides. Blakemore et al. first reported that microaerobic conditions (and therefore somemolecular oxygen) are required for $\mathrm{Fe}_{3} \mathrm{O}_{4}$ production by $\mathrm{M}$ agnetospirillum magnetotacticum ${ }^{53}$. Cells of this organism could grow in sealed, unshaken culture vessels with $0.1-21 \%$ oxygen in theheadspace; maximum $\mathrm{Fe}_{3} \mathrm{O}_{4}$ production and cellular magnetism occurred with an oxygen concentration of $1 \%$, whereas oxygen concentrations $>5 \%$ were inhibitory. Subsequent isotope experiments showed that molecular oxygen is not incorporated into $\mathrm{Fe}_{3} \mathrm{O}_{4}$, however, and that theoxygen in $\mathrm{Fe}_{3} \mathrm{O}_{4}$ is derived from water ${ }^{54}$. $\mathrm{So}$, the role of molecular oxygen in $\mathrm{Fe}_{3} \mathrm{O}_{4}$ synthesis is unknown, although it clearly affects the synthesis of specific proteins. For example, Sakaguchi and coworkers ${ }^{55}$ showed that thepresence of oxygen in nitrategrown cultures repressed the synthesis of a 140-kDa membrane protein in $M$. magnetotacticum, and Short and Blakemore ${ }^{56}$ showed that increasing the oxygen tension in cultures from $1 \%$ saturation to $10 \%$ caused cells to show increased activity of a manganese-type superoxide dismutase relative to that of an iron-type. The addition of nitrate to the growth medium as an additional terminal electron acceptor also seems to stimulate $\mathrm{Fe}_{3} \mathrm{O}_{4}$ production $-\mathrm{M}$. magnetotacticum is a microaerophilic denitrifier that converts nitrate to nitrous oxide $\left(\mathrm{N}_{2} \mathrm{O}\right)$ and dinitrogen, but which cannot grow under strict anaerobic conditions with nitrate ${ }^{8,53}$. Guerin and Blakemore ${ }^{77}$ reported anaerobic, Fe(III)dependent growth of $M$. magnetotacticum in the absence of nitrate. Cells grown anaerobically with poorly ordered (amorphous) Fe(III) oxides, presumably as the terminal electron acceptor, were extremely magnetic and produced nearly twice as many magnetosomes when compared with nitrate-grown cells with $1 \%$ oxygen in the headspace ${ }^{57}$. However, the cells grew very slowly under these conditions and the growth 
yields were poor compared with cells that weregrown on nitrateand/or oxygen. They further showed that, in this bacterium, $\mathrm{Fe}$ (॥) oxidation might also be linked to aerobic respiratory processes, energy conservation and $\mathrm{Fe}_{3} \mathrm{O}_{4}$ synthesis.

Schüler and Baeuerlein ${ }^{58}$ showed that $\mathrm{Fe}_{3} \mathrm{O}_{4}$ formation in M agnetospirillum gryphiswaldenseis induced in non-magnetotactic cells grown in a fermenter lacking a continuous oxygen-controlling system by a low threshold oxygen concentration of $\sim 2-7 \mu \mathrm{M}$ (1.7-6.0 mbar) at $30^{\circ} \mathrm{C}$. M agnetospirillum magneticum strain AM B- 1 synthesizes $\mathrm{Fe}_{3} \mathrm{O}_{4}$ either microaerobically or anaerobically using nitrate as the terminal el ectron acceptor ${ }^{59,60}$. The marinemagnetotactic vibrio, strain $\mathrm{MV}$ - 1 , synthesizes $\mathrm{Fe}_{3} \mathrm{O}_{4}$ microaerobically in semisolid agar oxygen-gradient cultures, and anaerobically under $1 \mathrm{~atm}$ of $\mathrm{N}_{2} \mathrm{O}$, which it uses as a terminal electron acceptor in respiration ${ }^{10}$.

Recently, H eyen and Schüler ${ }^{61}$ reported the effect of oxygen on the growth and magnetite magnetosome synthesis of M . gryphiswaldense, M . magnetotacticum and $M$. magneticum grown microaerobically in a continuous, oxygen-controlled fermenter. They found that for all three Magnetospi rillum strains, magnetite synthesis was only induced when the oxygen concentration was bel ow a threshold value of $20 \mathrm{mbar}$, and that the optimum oxygen concentration for magnetite biomineralization was $0.25 \mathrm{mbar}$.

\section{Synthesis of the bacterial magnetosome}

Synthesis of the bacterial magnetosome seems to bea complex process that involves several discrete steps, including magnetosome vesicle formation, iron uptake by the cell, iron transport into the magnetosome vesicle and controlled $\mathrm{Fe}_{3} \mathrm{O}_{4}$ (or $\mathrm{Fe}_{3} \mathrm{~S}_{4}$ ) biomineralization within themagnetosome vesicle (FIG.5). Although it is

a

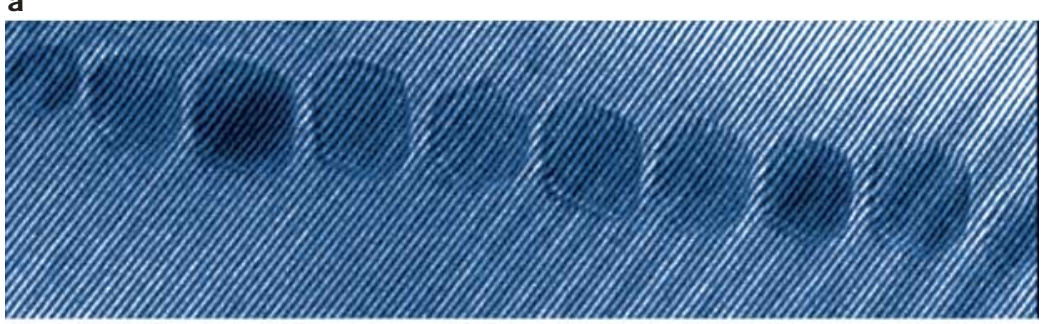

b

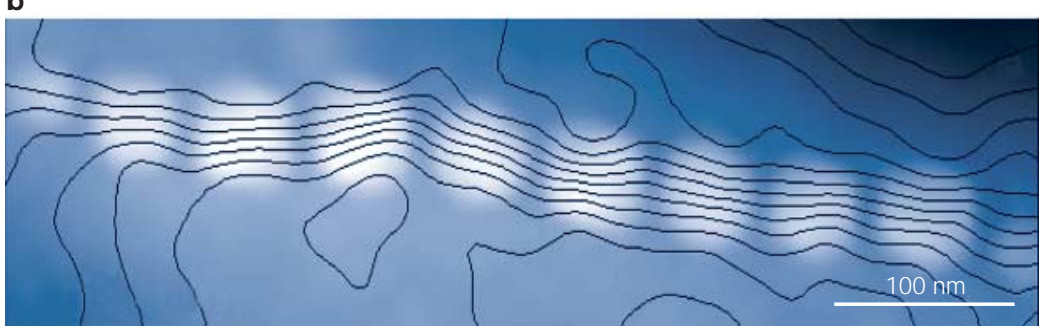

Figure 3 | Electron holography of a region of the magnetosome chain in Magnetospirillum magnetotacticum. a | Magnetosomes with the electron interference pattern. $\mathbf{b}$ | Magnetic field lines derived from the interference pattern superimposed on the positions of the magnetosomes. The confinement of the field lines within the magnetosomes is indicative of single magnetic domains and shows that the chain of magnetosomes acts as a single magnetic dipole. clear that the uptake, transport and mineralization steps are temporally ordered, it is unclear whether iron uptake precedes or follows vesicleformation, or if both steps occur simultaneously.

Iron uptake in magnetotactic bacteria. Despite thefact that magnetotactic bacteria consist of up to $3 \%$ iron as measured by dry weight ${ }^{3}-$ which is several orders of magnitude higher than non-magnetotactic species - at present there is no evidence to indicate that they use uniqueiron-uptake systems. Fe(I) is very soluble (up to $100 \mathrm{mM}$ at neutral $\mathrm{pH}^{62}$ ), and is generally taken up by bacteria by nonspecific mechanisms. H owever, Fe(III) is so insoluble that most microorganisms produce and rely on iron chelators, known as siderophores (BOX 2), which bind and solubilize Fe(III) for uptake. Siderophores are low-molecular weight $(<1 \mathrm{kD}$ a), specific ligands that are generally produced by bacteria under iron-limited conditions, and their synthesis is repressed under high-iron conditions ${ }^{63}$.

Frankel and co-worker $\mathrm{s}^{64}$ assumed that iron uptake by M . magnetotacticum was by a nonspecific tran sport system. In this study, iron was supplied as Fe(III) quinate, however, thegrowth medium also contained chemical reducing agents (for example, ascorbic acid) that are potent enough to reduce $\mathrm{Fe}($ (II) to $\mathrm{Fe}($ (I). So, both $\mathrm{Fe}(I)$ and $\mathrm{Fe}($ III) were present in the growth medium and it is unknown which form wastaken up by thecells; however, $M$. magnetotacticum was reported to producea hydroxamatesiderophore when grown under high $(20 \mu \mathrm{M})$, but not under low $(5 \mu \mathrm{M})$, iron conditions $5^{65}$, which indicates that cellscan takeup $\mathrm{Fe}$ (III) (thesiderophore production pattern hereis thereverse of what is normally observed).

Schüler and Baeuerlein ${ }^{66}$ havedescribed two ironuptake systems in M . gryphiswaldense. They showed that iron was mostly taken up as $\mathrm{Fe}($ III) and that this is an energy-dependent process. Fe(II) was also taken up by cells, but by a slow, diffusion-like process, whereas $\mathrm{Fe}$ (III) uptake followed Michaelis- M enten kinetics, which indicates that $\mathrm{Fe}($ (II) uptake by M . gryphiswaldense is a low-affinity, but high-velocity transport system. Although they found no evidencefor siderophoreproduction, theuse of spent culturefluid stimulated iron uptake by iron-depleted cells.

Nakamura et al. ${ }^{67}$ reported molecular evidencefor theinvolvement of a periplasmic-binding protein, SfuC, in the transport of iron by $M$. magneticum strain AM B-1. They did not detect siderophores in spent growth medium, although M . magneticum strain AM B-1 was recently found to produce both hydroxamate and phenolate siderophores ${ }^{68}$. Like M . magnetotacticum, M . magneticum strain AM B-1 produces siderophores under growth conditions that would be considered to be iron-sufficient, if not iron-rich, for thegrowth of most prokaryotes. This pattern of siderophore production might be explained by the fact that iron is taken up rapidly and converted to inert $\mathrm{Fe}_{3} \mathrm{O}_{4}$, which apparently cannot be used by cells. So, the concentration of iron that is available for growth probably decreases relatively quickly and the cells experience iron-limiting conditions, which stimulates siderophore production. 


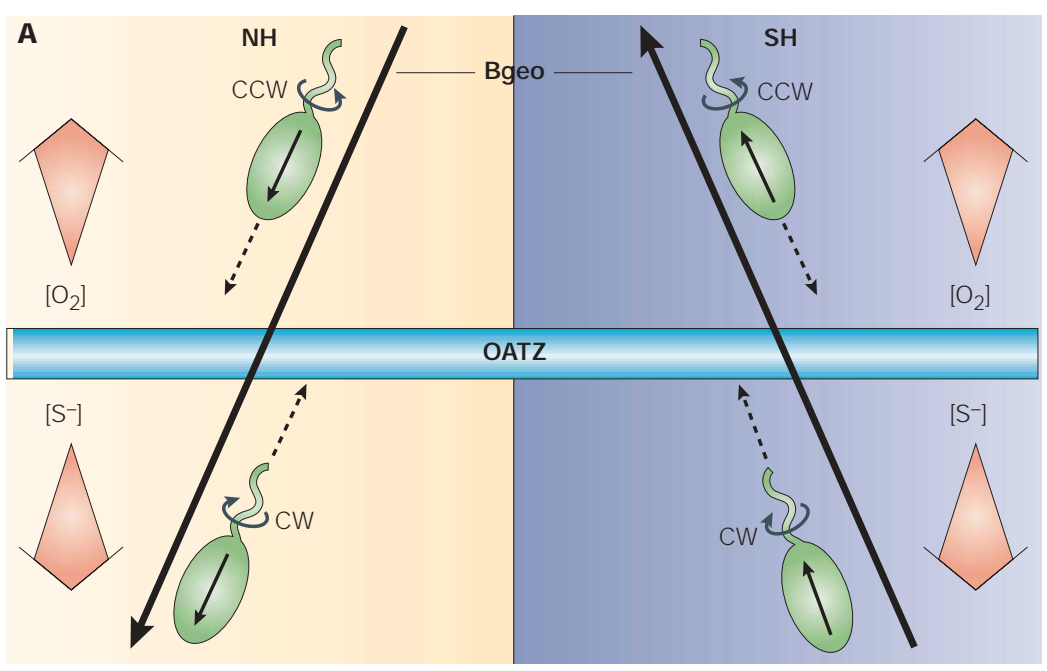

B

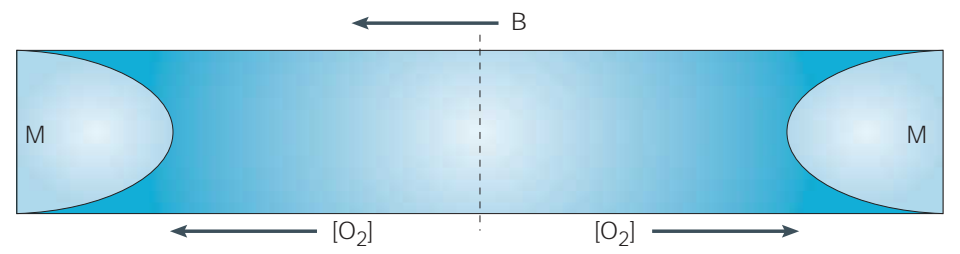

Axial magneto-aerotaxis

b

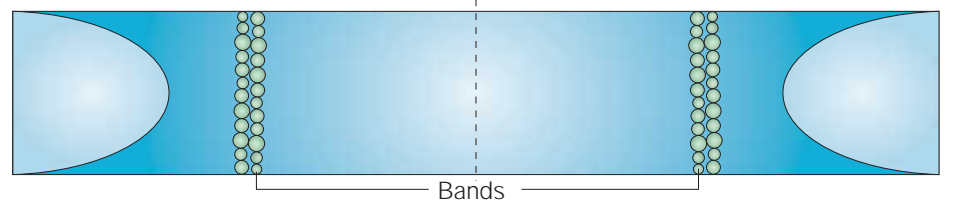

Polar magneto-aerotaxis

c

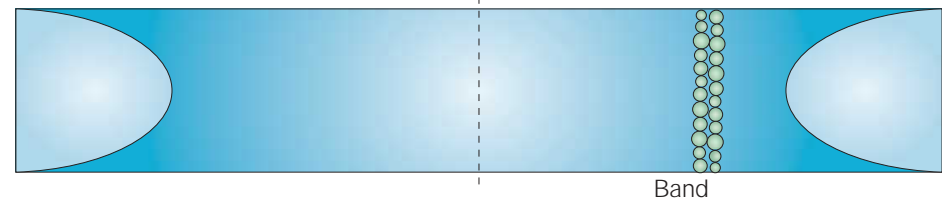

Figure 4 | Magneto-aerotaxis. A | Magneto-aerotaxis in the northern $(\mathrm{NH})$ and southern $(\mathrm{SH})$ hemispheres aids cells in efficiently finding their optimum oxygen concentration $\left(\left[\mathrm{O}_{2}\right]\right)$ at the microaerobic oxic-anoxic transition zone (OATZ) in water columns or sediments with horizontal chemical stratification (inverse concentration gradients of oxygen and hydrogen sulphide). In both hemispheres, cells on the oxic side of the OATZ swim down along the geomagnetic field lines $\left(B_{\text {geo }}\right)$ by rotating their flagella counterclockwise (CCW), whereas those on the anoxic side swim up along $B_{\text {geo }}$ by rotating their flagella clockwise (CW). This requires polar magnetoaerotactic cells in the $\mathrm{NH}$ and $\mathrm{SH}$ to have opposite magnetic polarity (shown by arrows inside cells). This means they exhibit north-seeking and south-seeking behaviour, respectively, when examined in oxic water droplets in a magnetic field. Axial magneto-aerotactic cells swim in both directions along the magnetic field. B | Determining axial and polar magneto-aerotaxis in bacteria. $\mathbf{B a} \mid$ Schematic drawing of a thin, flat capillary (cross section $0.2 \mathrm{~mm} \times 5 \mathrm{~mm}$ ) that is used to distinguish between polar and axial magneto-aerotactic bacteria. Cell suspensions of magnetotactic bacteria in reduced growth medium are drawn up in the capillaries, resulting in a meniscus $(M)$ at both ends. Oxygen diffuses into the medium from the open ends of the capillaries resulting in an oxygen-concentration gradient, $\left[\mathrm{O}_{2}\right]$, that increases from the centre of the capillary towards each end. The tube is placed in a static magnetic field $(B)$, which is of the order of a few gauss and is oriented along the tube. $\mathbf{B} \mathbf{b} \mid$ Band formation by axial magnetoaerotactic cells, such as Magnetospirillum magnetotacticum, occurs at both ends of the capillary. Rotation of the magnetic field by $180^{\circ}$ after formation of the bands causes the cells in both bands to rotate $180^{\circ}$, but the bands remain intact. BC | Band formation by polar magnetoaerotactic cells, such as the marine coccus, strain MC-1, occurs only at the end of the capillary for which the magnetic field and the oxygen concentration gradient are oriented opposite to each other. Rotation of the magnetic field by $180^{\circ}$ after formation of the band causes the cells in the band to rotate $180^{\circ}$ and swim away, resulting in dispersal of the band.
Recently, we have found that strain M V-1 also produces a siderophore (B.L. Dubbels, A.A. DiSpirito, J.D. M orton, J.D. Semrau \& D.A.B., manuscript in preparation). It seems to be a hydroxamate type and thepattern of siderophoreproduction under different iron concentrations is similar to that observed for the Magnetospirillum species. Wehavealso found biochemical and molecular evidencefor the presence of a copperdependent, high-affinity iron-uptakesystem in strain M V-1 (B.L. Dubbels, A.A. DiSpirito, J.D. Morton, J.D. Semrau \& D.A.B., manuscript in preparation), which is similar to the system that is found in the yeast Saccharomyces cerevisiae ${ }^{69}$.

Magnetosome vesicle formation. The magnetosome membrane in several $M$ agnetospirillum species has been shown to consist of a lipid bilayer about 3- $4 \mathrm{~nm}$ thick ${ }^{70}$, comprising phospholipids, fatty acids and some proteins that are similar to those found in the cytoplasmic membrane ${ }^{70}$ (FIG.6). This indicates that the magnetosome membrane vesicle originates from the cytoplasmic membrane and might bethe reason why magnetosomes in almost all of the magnetotactic bacteria seem to be anchored to the cytoplasmic membrane, as shown by electron microscopy and electron tomography. However, there is no direct, unequivocal evidence for the contiguity of these two membranes. Nonetheless, the current belief is that the magnetosome membrane vesicle is created by invagination and 'pinching off' of the cytoplasmic membrane. An important question that is yet to be answered is whether the vesicle is produced before $\mathrm{Fe}_{3} \mathrm{O}_{4}$ nucleation and precipitation, or whether $\mathrm{Fe}_{3} \mathrm{O}_{4}$ nucleation takes place in the periplasm and the cytoplasmic membraneinvaginates around the developing crystal. There is some evidence for the former as apparently empty and partially filled magnetosome vesicles have been observed in iron-starved cells of M. magnetotacticum ${ }^{70}$ and strain M V-1.

Small GTPases, such as Sar1p, are known to be essential for the budding reaction in the production of membranevesicles and vesicle trafficking in eukaryotes ${ }^{71}$. O kamura et al. ${ }^{72}$ identified a $16-k D$ a protein that has GTPaseactivity - known as M ms16 - in the magnetosome membrane vesicle of $M$. magneticum strain AM B-1, where it was the most abundant of five proteins present. Cells that were grown in the presence of a GTPase inhibitor showed less overall magnetism and produced fewer magnetosomesthan thosegrown in the absence of a GTPase inhibitor, which indicates that GTPase activity is required for magnetosome synthesis. A protein with high sequence similarity to M ms16 was recently shown to beinvolved in polyhydroxybutyrate depolymerization in the photosynthetic bacterium Rhodospirillum rubrum ${ }^{73}$.

Iron transport into themagnetosomemembranevesicle. From an early stage in magnetosome research, electron microscopy has been used to show $\mathrm{Fe}_{3} \mathrm{O}_{4}$ crystals in various stages of maturity, and that these crystals increase in size within magnetosome vesicles. So, regardless of 


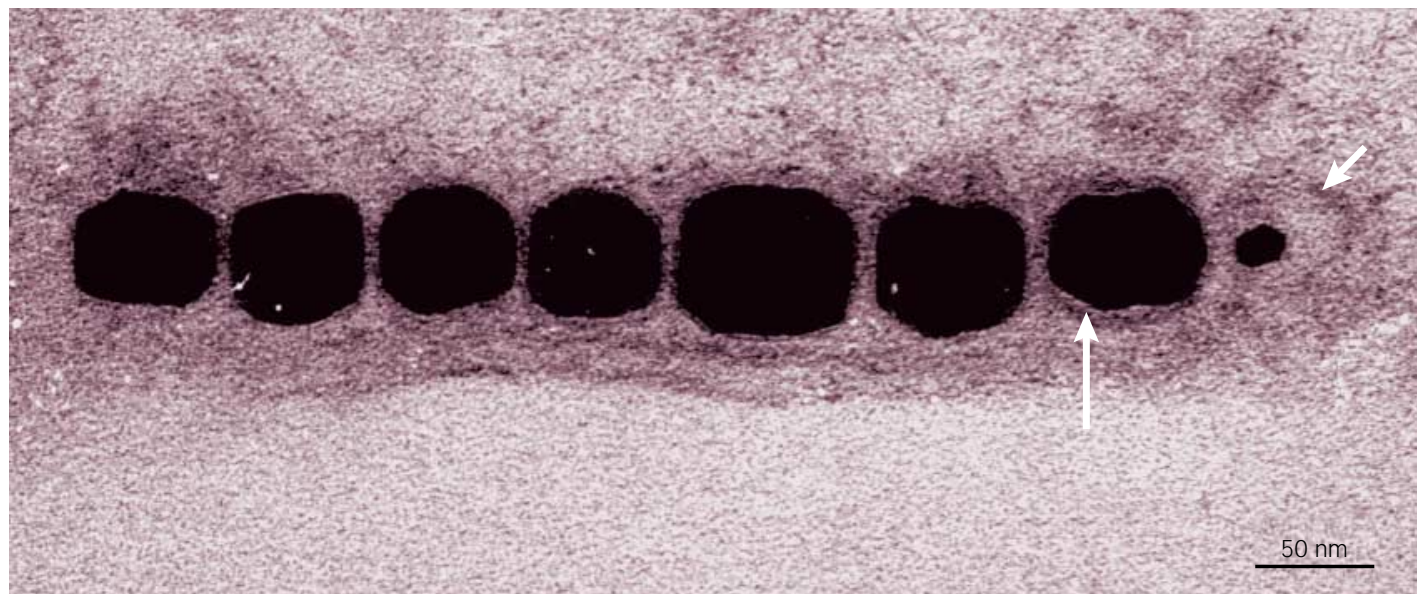

Figure 5 | Transmission electron micrograph of a thin section of a magnetosome chain in a cell of the marine spirillum strain MV-4. The magnetosome membrane is shown as an electron-dense coating surrounding the magnetite crystals. The membrane seems to be pulled away from the crystal at the long arrow, and the short arrow indicates a partially filled magnetosome vesicle. The magnetosome membrane is often difficult to visualize around all the magnetite particles owing to its close proximity to the crystal. Sometimes, the thin section must be tilted in the electron beam. Immature magnetite crystals are often observed at the ends of the chain in magnetotactic bacteria. Image courtesy of T. J. Beveridge.

when themagnetosomemembranevesicleisformed, additional iron must betransported into thevesiclefor the crystal to grow.

It is not known which redox forms of iron are transported into the magnetosome vesicle in most magnetotactic bacteria, but there is evidence that $\mathrm{Fe}($ II) is transported into vesicles of $\mathrm{M}$. magneticum strain AM B-1 (REF. 74). Using transposon mutagenesis, Nakamura and co-workers ${ }^{74,75}$ identified a gene, magA, that encodes a protein with significant sequence homology to the cation-efflux proteins, KefC, a
$\mathrm{K}^{+}$-translocating protein in Escherichia coli, and NapA, a putative $\mathrm{Na}^{+} / \mathrm{H}^{+}$antiporter from Enterococcus hirae. The MagA protein is present in both the cytoplasmic and magnetosome membranes of $M$. magneticum strain AM B-1. magA was expressed in E. coli and inverted membrane vesicles prepared from these cells were shown to transport Fe(I) in an energy-dependent manner, leading to accumulation of $\mathrm{Fe}($ (I) in the vesicle, which indicates that $\mathrm{M}$ agA functions as a $\mathrm{H}^{+} / \mathrm{Fe}\left({ }^{\prime \prime}\right)$ antiporter in M. magneticum strain AM B-1. However, magA expression was higher when cells of wild-type

\section{B ox 2 | Siderophores in bacteria}

Siderophores are relatively low-molecular weight (most are between 0.5 to $1.5 \mathrm{kDa}$ ), $\mathrm{Fe}(\mathrm{III}$ )-specific chelating compounds that are produced by most prokaryotes and fungi under environmental conditions wheretheconcentration of biologically availableiron is low $^{123}$. I ron is a required nutrient for all but a few species of organisms and is used for many essential purposes. Despite the fact that iron is the fourth most abundant element on Earth, most iron is not biologically available because, under aerobic atmospheric conditions, $\mathrm{Fe}_{(I I I)}$ exists predominantly in the form of $\mathrm{Fe}(\mathrm{III})$ oxyhydroxides, which are almost insolubleat neutral $\mathrm{pH}^{62}$. As a result, the maximum concentration of uncomplexed $\mathrm{Fe}(\mathrm{III})$ in solution has been estimated at $10^{-18} \mathrm{M}$ (REF. 124). Microorganisms requirea minimum effectiveiron concentration of $\sim 0.01 \mu \mathrm{M}$ for growth, but $\sim 1 \mu \mathrm{M}$ for optimal growth ${ }^{125}$. Siderophores are a mechanism by which microorganisms can scavengeiron from nonsolublesources, and somemicroorganisms can even usesiderophores that are produced by different species.

Siderophores can be divided into four broad groups based on the chemical type of the chelating ligands in the molecule: catecholates, hydroxamates, hydroxypyridonates and aminocarboxylates ${ }^{125}$. There are approximately 200 recognized siderophores, and most are catecholates and hydroxamates. Some well-characterized examples include the catecholate enterobactin that is produced by Escherichia coli and the trihydroxamic acid desferriferrioxamine B that is produced by the Gram-positive actinomycete Streptomyces pylosus. The latter has been used in humans in iron-chelation therapy ${ }^{126}$.

Much of the work involving the transport of Fe(III)- siderophore complexes has been done using E. coli. Despite the low-molecular mass of the siderophore itself, the $\mathrm{Fe}$ (III)-siderophore complex is too large to passively diffuse across the outer and inner membranes of a Gram-negative bacterium, or to be taken up by nonspecific methods. Uptake of the Fe(III)-siderophore complex is receptor- and energy-dependent. The binding of the complex to the outer membrane receptor is usually very specific. The transport of the $\mathrm{Fe}$ (III)- siderophore complex across the outer membrane into the periplasm requires an energy-transducing complex composed of the proteins TonB, ExbB and ExbD. In the periplasm, the $\mathrm{Fe}($ III)-siderophore complex binds to its cognate binding protein and is actively transported by an ATP-transporter system across the cytoplasmic membrane to the cytoplasm ${ }^{127}$. It can be concluded that if most of the iron in magnetosomes is transported by cells through the use of siderophores, then the cell is probably expending a significant amount of energy on iron uptake. 


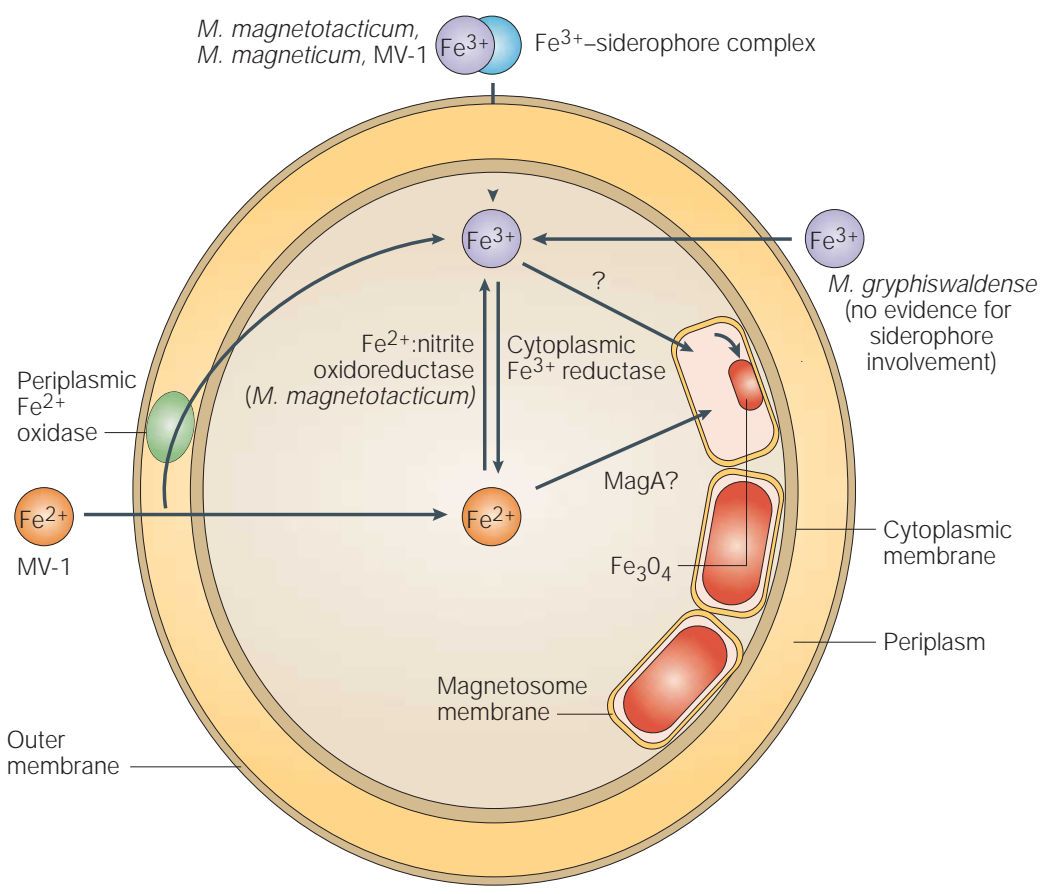

Figure 6 | Schematic of possible reactions leading to magnetite biomineralization in known, cultured species of magnetotactic bacteria. $\mathrm{Fe}($ (II) $)$ is actively taken up by cells of Magnetospirillum gryphiswaldense, with no evidence of the involvement of a siderophore ${ }^{66}$. It is likely that cells of the other Magnetospirillum strains and strain MV-1 also take up Fe(II) as it is thought that they form siderophores (REFS65,68; B.L. Dubbels, A.A. DiSpirito, J .D. Morton, J.D. Semrau $\&$ D.A.B., manuscript in preparation), although it is not known what proportion of the iron in the magnetosomes is taken up as $\mathrm{Fe}($ (II) by these organisms. The siderophore-bound $\mathrm{Fe}($ (I) is probably reduced to $\mathrm{Fe}(॥)$. At least $70 \%$ of the iron in the culture medium that is used to grow strain MV-1 is present as Fe(॥), so it is likely that much of the iron that is taken up by this strain is of the form $\mathrm{Fe}(॥)$. A periplasmic, multicopper-containing $\mathrm{Fe}(॥)$ oxidase has been purified from this organism that could be involved in the transport of iron into the cytoplasm (B.L. Dubbels, A.A. DiSpirito, J .D. Morton, J .D. Semrau \& D.A.B., manuscript in preparation). A protein capable of $\mathrm{Fe}(॥)$ oxidation ${ }^{99}$ has also been found and purified from Magnetospirillum magnetotacticum. A cytoplasmic Fe(II) reductase activity is present in strain MV-1 (B.L. Dubbels, A.A. DiS pirito, J .D. Morton, J .D. Semrau \& D.A.B., manuscript in preparation) and a cytoplasmic $\mathrm{Fe}(\mathrm{M})$ reductase has been purified from $\mathrm{M}$. magnetotacticum ${ }^{103}$. There is some evidence that in Magnetospirillum magneticum, MagA - a protein that is found in the cytoplasm and the magnetosome membranes of $\mathrm{M}$. magneticum - functions as an $\mathrm{H}^{+} / \mathrm{Fe}(\|)$ antiporter ${ }^{74,75}$. Other proteins possibly responsible for, or involved in, iron transport into the magnetosome membrane vesicle are MamB and MamM - proteins that are abundant in the magnetosome membranes of M. gryphiswaldense ${ }^{77}$. Iron that is transported into the magnetosome membrane vesicle in M. magnetotacticum is then thought to form a high-density hydrous $\mathrm{Fe}($ (II) oxide (ferrihydrite; $\mathrm{Fe}_{2} \mathrm{O}_{3} \cdot \mathrm{nH}_{2} \mathrm{O}$ ); reduction of one-third of the $\mathrm{Fe}(\mathrm{II})$ ions and adjustment of the $\mathrm{pH}$ results in nucleation of the magnetite crystal within the magnetosome vesicle ${ }^{64}$. The nucleation step might involve the adsorption of aqueous $\mathrm{Fe}(\Perp)$ ions onto the surface of the hydrous iron oxide ${ }^{82,83}$.

M . magneticum strain AM B-1 weregrown under ironlimited conditions, rather than under iron-sufficient conditions where they producemore magnetosomes. So, even though M agA seems to be involved in iron transport, it is not solely responsiblefor magnetosome synthesis. Genes that share significant sequence homology with magA are present in $M$. magnetotacticum and theunnamed magnetotactic coccus, strain M C-1 (REF. 76).

Two other proteins that are abundant in the magnetosomemembrane of $M$. gryphiswaldense - M amB and $\mathrm{MamM}$ - might also beinvolved in the transport of iron into magnetosomevesicles ${ }^{77}$. Both proteins seem to belong to a group of heavy-metal-ion-transporting proteins that is known as the cation diffusion facilitator (CDF) family ${ }^{78,79}$ (BOX 3). A spontaneous non-magnetotactic mutant of $M$. gryphiswaldense, which lacks mamB and mamM , as well as numerous other magnetosomemembrane proteins and other genes, and which does not biomineralize magnetosomes (discussed below), was found to be deficient in iron uptake ${ }^{77}$. Iron has not been unequivocally shown to be bound and transported by any known CDF protein, although in the yeast $\mathrm{S}$. cerevisiae, the overexpression of two genes that encode mitochondrial membrane proteins affects $\mathrm{Fe}\left({ }^{\prime \prime}\right)$ concentrations in the mitochondria and cytoso ${ }^{80}$. Although these genes have been referred to as mitochondrial iron transporters (M FT; M FT1 and M FT2) ${ }^{80}$, deletion of either or both genes did not affect essential $\mathrm{Fe}^{2+}$-dependent processes in themitochondrion, leaving the specific role of thesegenes unclear ${ }^{81}$.

Controlled $\mathrm{Fe}_{3} \mathrm{O}_{4}$ biomineralization within themagnetosomevesicle. Frankel et al. ${ }^{64}$ have proposed a model in which $\mathrm{Fe}($ (II) is taken up by the cell, reduced to $\mathrm{Fe}(I)$ and then transported to the magnetosome membrane vesicle. It is then thought to be reoxidized to form hydrous $\mathrm{Fe}($ (II) oxides, which aresimilar to the mineral ferrihydrite In thefinal step, one-third of theFe(III) ions in the hydrous oxides are reduced and, with further dehydration, $\mathrm{Fe}_{3} \mathrm{O}_{4}$ is produced. The crucial step in the transformation of hydrous iron oxides to magnetite in vitro involves theadsorption of aqueous $\mathrm{Fe}($ II) ions onto the surface of the hydrous iron oxide ${ }^{82,83}$. Schüler and Baeuerlein ${ }^{58}$ have subsequently shown that, in $M$. gryphiswaldense, Fe(III) istaken up and rapidly converted to $\mathrm{Fe}_{3} \mathrm{O}_{4}$ without any apparent delay, indicating that there is no significant accumulation of an $\mathrm{Fe}_{3} \mathrm{O}_{4}$ precursor inside the cell, at least under the microaerobic conditions of the experiment, which were apparently optimal for $\mathrm{Fe}_{3} \mathrm{O}_{4}$ production by $\mathrm{M}$. gryphiswaldense.

The size and shape of the magnetosome mineral phase has long been thought to becontrolled by the magnetosome membrane vesicle, although the exact mechanism by which this occurs is unclear. Perhaps certain proteins are distributed asymmetrically in the magnetosome membrane, thereby facilitating crystal growth in certain directions but retarding it in others. It is also possiblethat themagnetosome membrane vesicle places physical constraints on the growing crystal, thereby limiting its size. Arakaki and co-workers ${ }^{26}$ partially characterized several magnetosomemembrane proteins that weretightly bound to $\mathrm{Fe}_{3} \mathrm{O}_{4}$ crystals in $M$. magneticum strain AM B-1, including M ms5, M ms6, $\mathrm{M}$ ms7 and M ms13. M ms6 was overexpressed in E. coli, purified and found to bind iron. M ore importantly, $\mathrm{Fe}_{3} \mathrm{O}_{4}$ crystals that were formed chemically in the presence of M ms6 had a sizerange of about 20-30 nm and a cuboidal morphology similar to those produced by intact cells (FIG. 7). Those produced in the absence of M ms6 were non-homogeneous in shape and were 1-100 nm in size. All four M ms proteins contain hydrophobic amino-terminal and hydrophilic carboxy-terminal regions, thelatter being rich in carboxyl and hydroxyl groups that arethought to bind iron. All 


\section{B ox 3 | Cation diffusion facilitator proteins}

The cation diffusion facilitator (CDF) protein family is a diverse family of heavy metal ion transporters (metal/ $\mathrm{H}^{+}$antiporters ${ }^{81}$ ) that is found in both prokaryotes and eukaryotes ${ }^{79,81}$. Many CDF genes were discovered through overexpression experiments that resulted in the resistance of an organism to the toxicity of a specific metal ${ }^{81}$. They show an unusual degree of size variation, sequence divergence and polarity, and can catalyze the influx or efflux of metal ions ${ }^{79}$. In addition, there are differences in the cellular localization of the protein (they can be localized in specific organelles in eukaryotes) and some have been shown to affect the cellular distribution of specific metals $s^{81}$. All recognized CDF proteins contain six putative transmembrane-spanning domains, with the highest amino-acid sequence conservation in the four aminoterminal spanning domains ${ }^{79}$. Eukaryotic CDF proteins also possess histidine-rich cytoplasmic loops between transmembrane-spanning domains 4 and 5 (REF. 79). Heavy metals that have been shown to be transported by CDF proteins include cobalt, cadmium and zinc ${ }^{79}$.

four M ms proteins also have the common amino-acid sequenceLGLGLGLGAWGPXXLGXXGXAGA. AsMms7 and $M$ msl3 show very high sequence identity to the $\mathrm{MamD}$ and $\mathrm{MamC}$ proteins in $\mathrm{M}$. gryphiswaldense, respectively, they should be considered as identical, equivalent proteins and therefore should retain the names $M$ amD and M amC (seenext section).

\section{Other proteins and genes \\ Magnetosome membrane proteins. O kuda et al. ${ }^{84}$ identified three magnetosome membrane proteins with molecular weights of 12,22 and $28 \mathrm{kDa}$ in $M$. magnetotacticum. The gene encoding the $22-\mathrm{kD}$ a protein was cloned and sequenced, and the amino-acid sequence showed significant homology to proteins of the tetratricopeptide repeat protein (TPR) family (BOX 4), including mitochondrial and peroxisomal protein import receptors. It was proposed that this protein functions as a receptor that interacts with associated cytoplasmic proteins. The mam 22 genewas expressed in E. coli and the resultant protein partially characterized ${ }^{85}$. A structural model of Mam22 was proposed, which contains five TPR repeats and a putative sixth repeat.}

a
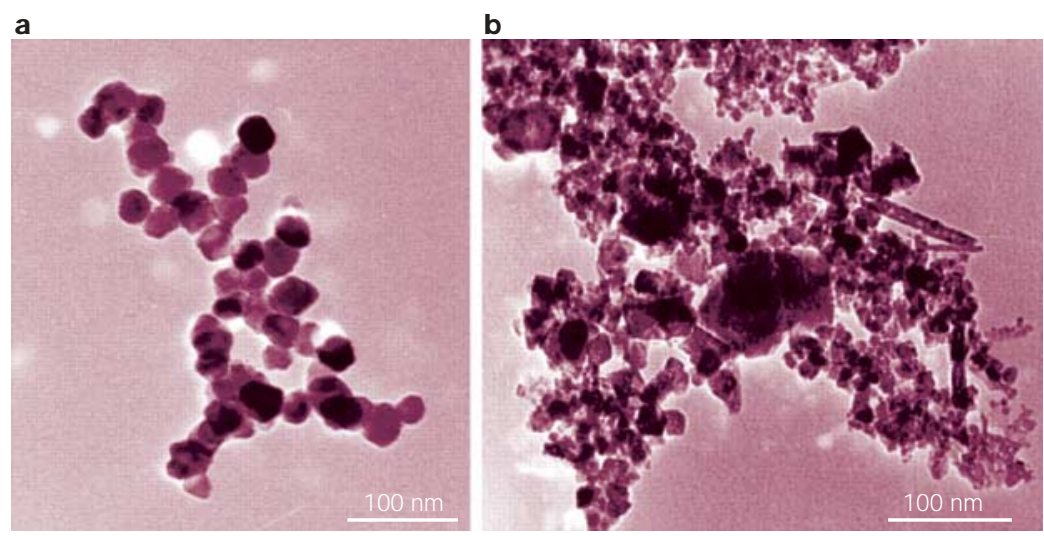

Figure $7 \mid$ The effects of a magnetosome membrane protein, Mms6, on magnetite formation. a | $\mathrm{Fe}_{3} \mathrm{O}_{4}$ crystals produced in the presence of $\mathrm{Mms} 6$ had a size range of 20-30 nm, with a cuboidal morphology similar to those produced by intact cells. $\mathbf{b} \mid \mathrm{Fe}_{3} \mathrm{O}_{4}$ crystals produced in the absence of $\mathrm{Mms} 6$ are non-homogeneous in shape and range in size from 1 to $100 \mathrm{~nm}$. Image courtesy of T. Matsunaga. Reproduced with permission from REF. 26 (c) (2003) American Society for B iochemistry and Molecular Biology.
A similar protein, called MamA, and/or genes encoding similar proteins have been found in $\mathrm{M}$. gryphiswaldense and strain MC-1 (REF. 76).

Grünberg et al. ${ }^{76}$ Cloned and sequenced the genes encoding several $M$ am proteinsin $M$. gryphiswaldense that had been assigned to two different genomic regions. These proteins exhibited thefollowing homologies: $M$ amA to TPR proteins (BOX 4); $M$ amB to CDF proteins (BOX 3); and $\mathrm{M}$ amE to $\mathrm{H}$ trA-like serine proteases (BOX 5). The sequences of $M$ amC and MamD only show homology to some of the $M$ ms proteins described in the previous section. Other putativegenes in these genomic regions were al so conserved and might encode other magnetosome membrane proteins. Similar gene clusters containing homologues to mamA and mamB and additional genes with no homology to known genes or proteins in established databases have been found in M. magnetotacticum and strain M C-1. H owever, it was not shown whether the homologous genes in strain M C-1 actually encode magnetosome membrane proteins in this organism, although we recently confirmed that the mamC gene encodes a magnetosome membrane protein in strain MC-1.

Several research groups have observed thefrequent formation of spontaneous non-magnetotactic mutants of several magnetotactic bacterial strains, including M. gryphiswaldenseand strain M V-1, which do not synthesize magnetosomes. These mutants do not contain intracellular vesicles and neither take up nor accumulate the large amounts of iron that are observed in the wildtype strains. Schüler and co-workers ${ }^{77}$ have recently shown that one of these mutants has a chromosomal deletion of an $\sim 80 \mathrm{~kb}$ region of $D N A$, which contains several insertion sequences, the mam genes and additional genesthat encode magnetosomemembrane proteins. The mam genes are localized in a 35-kb region of the deletion, so this area could represent a magnetosome genomic island. Genomic islands are large regions of DNA that contain genes linked to a metabolic activity or function and that are capable of horizontal gene transfer. We have preliminary evidence to show that a similar situation existsin strain M V-1.

Genomic islands often have a different $\mathrm{G}+\mathrm{C}$ content to the rest of the genome ${ }^{86}$. They are also known to be flanked by several types of mobile genetic elements, including direct repeats, insertion sequences, integrases, transposases, proximal transfer RNAs and areas of atypical $G+C$ content, which are responsiblefor the mobilization of the island. O wing to these flanking elements, genomic islands not only have a tendency to delete from genomes with high frequency, they can also undergo duplications, amplifications and rearrangements ${ }^{87,88}$. The possibility that the genes that are responsible for magnetite magnetosome synthesis are part of a genomic island could bethe reason why this trait is observed in many diverse bacteria and could also explain why this trait seems to be easily lost in several strains of magnetotactic bacteria.

$M$ atsunaga et al. ${ }^{89}$ identified three important magnetosome membrane proteins with molecular masses of approximately $24.8,35.6$ and $66.2 \mathrm{kD}$ a in 
Box 4 | Tetratricopeptide repeat proteins

Thetetratricopeptiderepeat (TPR) is a degenerate sequence of 34 amino acids that is known to be present in $>25$ proteins of varying function in both prokaryotes and eukaryotes ${ }^{128-130}$. Sequencealignment of TPR domains reveals a consensus sequence consisting of a pattern of small and large hydrophobic amino acids ${ }^{131}$. TPRsare usually arranged in tandem arrays of 3-16 motifs, although occasionally, in some proteins, individual motifs or blocks of motifs can bedispersed throughout the protein sequence. Multiplecopies of TPRs form scaffolds within proteins to mediate protein- protein interactions. They areknown to coordinatetheassembly of proteins into multisubunit complexes ${ }^{132}$.TPRs werefirst recognized in theeukaryotic cell-division protein subunits CDC16, CDC23 and CD C27, which comprise the anaphase promoting complex ${ }^{129}$. ProteinscontainingTPRsare now also known to beinvolved in other processes, including protein folding, mitochondrial and peroxisomal protein transport, protein kinaseinhibition, Rac-mediated activation of NADPH oxidase, neurogenesis, transcriptional control and protein phosphatase activity ${ }^{128,130,131}$. Recently, a model for TPR-mediated protein recognition was reported for theenzymeserine/threonine phosphatase PP5 (REF. 128).

M . magneticum strain AM B-1. The gene encoding the 35.6-kD a protein, mpsA, was cloned and the protein sequenced. M psA was found to have homology with the $\alpha$-subunits of acetyl-CoA carboxylases and the CoA-binding motif. At present, the function of this protein is unknown.

A series of non-magnetotactic mutants of $M$. magneticum strain AMB-1 was generated by mini-Tn5 transposon mutagenesis ${ }^{90}$. O ne of these, designated strain NM A21, was recently isolated and characterized ${ }^{91}$. The transposon was found to have disrupted a gene encoding a protein with high sequencehomology to a tungsten-containing aldehyde ferredoxin oxidoreductase from the hyperthermophilic archaeon Pyrococcus furiosis. The protein was produced under microaerobic conditions and was cytoplasmic. Cells of N M A21 did not produce magnetosomes and the rates of iron uptake and growth of this mutant strain werelower than those of thewild-typestrain.

Nitrogen oxide, iron reduction and oxidation. To understand the relationship between nitrate and oxygen utilization and $\mathrm{Fe}_{3} \mathrm{O}_{4}$ synthesis in $\mathrm{M}$. magnetotacticum, Fukumori and co-workers examined electron transport and cytochromes in this organism. Tamegai et al. ${ }^{92}$ purified and characterized a novel 'cytochromea $a_{1}$-like' haemoprotein that was found to be present in greater amounts in magnetic cells than non-magnetic cells. There was no evidence for the presence of a cytochrome $a_{1}$, oncereported to be one of theterminal oxidases, or an o-type cytochrome in $\mathrm{M}$. magneto-

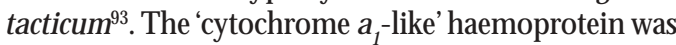
composed of two different subunits with molecular masses of $41 \mathrm{kDa}$ (subunit I) and $17 \mathrm{kDa}$ (subunit II), and exhibited very littlecytochromec oxidase activity. The genes encoding this unusual cytochrome were identified and sequenced ${ }^{94}$. Three open reading frames preceded by a putative ribosome-binding site were found in the sequenced region and designated mcall, mcal and hosA. mcal and mcall wereshown to encode subunits I and II of the'cytochrome $a_{1}$-like' haemoprotein, respectively. hosA showed significant sequence homology to the gene encoding haem o synthase (protohaem IX farnesyltransferase), an essential enzyme for the biosynthesis of haem 0 and haem a ${ }^{95}$. Although six histidine residues that were predicted to associate with prosthetic cofactors of the haem-copper oxidase superfamily were conserved in the'cytochrome $a_{1}$-like' haemoprotein, none of the amino acid residues that were proposed to participate in the oxygenreducing and the coupled proton-pumping reactions in cytochrome coxidase in Paracoccus denitrificans ${ }^{96}$ were conserved in subunit I. Thelatter finding probably explains theobserved poor cytochromec oxidase activity of the protein.

A new cdb-type cytochromec oxidase ${ }^{97}$, a cytochrome $c-550$ that is homologous to cytochrome $c_{2}$ in some photosynthetic bacteria ${ }^{98}$ and a cytochrome cd -type nitrite reductase ${ }^{99}$ were identified and purified from M. magnetotacticum. The latter protein might be important in $\mathrm{Fe}_{3} \mathrm{O}_{4}$ biomineralization as it has a novel $\mathrm{Fe}(\Perp)$ :nitrite oxidoreductase activity that might belinked to the oxidation of $\mathrm{Fe}($ II) in the cell and, therefore, to $\mathrm{Fe}_{3} \mathrm{O}_{4}$ synthesis. Recently, a soluble periplasmic nitrate reductase was purified from $M$. magnetotacti cum ${ }^{100}$. The enzyme comprises two subunits of 86 and $17 \mathrm{kDa}$ and contains molybdenum, non-haem iron and haem c. M olybdenum starvation of cells resulted in little periplasmic nitrate reductase activity in cell-free extracts, but the magnetosome fraction still had almost half theiron that was present in the same fraction of cells grown with molybdenum. These results indicate that nitrate reduction in this organism is not essential for $\mathrm{Fe}_{3} \mathrm{O}_{4}$ synthesis.

Several species of magnetotactic bacteria reduce or oxidize iron either as intact whole cells, as cell-free extracts or both. Cells of $\mathrm{M}$. magnetotacticum reduce $\mathrm{Fe}\left({ }_{I I I}\right)^{57}$ and translocate protons when $\mathrm{Fe}($ III) is introduced anaerobically ${ }^{101}$, indicating that cells conserve energy during the reduction of $\mathrm{Fe}($ III). Growth yields on $\mathrm{Fe}($ III) indicate that iron reduction is also linked to growth, as is found in the dissimilatory iron-reducing bacteria ${ }^{57}$. Fe(III) reductase activity has al so been shown in cell-free extracts of $M$. magnetotacticum ${ }^{102}$ and strain MV-1 (B.L. Dubbels, A.A. DiSpirito, J.D. M orton, J.D. Semrau \& D.A.B. manuscript in preparation), and an $\mathrm{Fe}($ ॥I) reductase was purified from M. magnetotacticum ${ }^{103}$. The enzyme seems to be loosely bound to the cytoplasmic face of the cytoplasmic membrane, has an apparent molecular weight of $36 \mathrm{kDa}$, and requires reduced nicotinamide adenine dinucleotideand flavin mononucleotideas an electron donor and cofactor, respectively. Enzyme activity was inhibited by zinc, which also reduced the number of magnetosomes when included in the growth medium as $\mathrm{ZnSO}_{4}$

Genetic systems in the magnetotactic bacteria It is unknown how many, or which, genes and proteins are required for $\mathrm{Fe}_{3} \mathrm{O}_{4}$ magnetosomesynthesis, or how these genes are regulated. Establishing a genetic system with the magnetotactic bacteria is an absolute necessity to answer these questions. In many ways, progress in the elucidation of the chemical and biochemical pathways 
Box 5 | The HtrA family of serine proteases

H trA (also known as D egP) is an envelope-associated serine protease that was first discovered in Escherichia coli and is induced by heat-shock ${ }^{133}$. Theenzymatic activity of $\mathrm{H}$ trA occurs in the periplasm, whereits main roleseems to bein the degradation of misfolded proteins ${ }^{134}$. Although H trA has a significant rolein 'cellular cleaning', these proteases arealso involved in non-destructive protein processing and modulation of signalling pathways by degrading important regulatory proteins. Homologues of $\mathrm{H}$ trA havenow been discovered in diverse bacteria and in someeukaryotes, including yeasts, plants and humans ${ }^{134}$. All have at least one PDZ domain - a region of sequencehomology that has been found in a large number of diverse signalling proteins ${ }^{134}$. PDZ domains are known to beinvolved in a range of protein-protein interactions and mediatetheassembly of specific multi-protein complexes by recruiting downstream proteins in a signalling pathway ${ }^{134,135}$. ThehtrA genehas practical significance and can be used in several commercial and medical applications ${ }^{134}$. For example, htrA mutants of several Gramnegative pathogens becomeattenuated in animal models, so cells of thesemutant strains could potentially be used as live vaccines. These mutants might also have potential biotechnological applications as they show improved expression of envelope-associated proteins.

that are involved in $\mathrm{Fe}_{3} \mathrm{O}_{4}$ magnetosome synthesis, particularly in determining the function of specific proteins, has been limited by the general absence of a workable genetic system in the magnetotactic bacteria. There are still many problems in establishing genetic systems in the magnetotactic bacteria, including the lack of a significant number of magnetotactic bacterial strains. In addition, their fastidiousness and general microaerophilic nature require elaborate growth techniques, and they are difficult to grow on the surface of agar plates, which would enable the screening for mutants. M oreover, there is a lack of effective methods of DNA transfer in these microorganisms. However, this situation is improving rapidly.

Waleh and co-workers initiated the first studies in the establishment of a genetic system in magnetotactic bacteria. They showed that some of the genes from $M$. magnetotacticum can be functionally expressed in E. coli and that the transcriptional and translational elements of the two microorganisms are compatible, a feature that is necessary for a genetic system ${ }^{104}$. They cloned, sequenced and characterized the recA gene from M. magnetotacticum ${ }^{105,106}$. Focusing on iron uptake in $M$. magnetotacticum, they also cloned and characterized a 2-kb DNA fragment that complemented the aroD (biosynthetic dehydroquinase) gene function in E. coli and Salmonella enterica serovar Typhimurium ${ }^{107}$. aroD mutants of these strains cannot takeup iron from the growth medium. When the 2-kb DNA fragment from $M$. magnetotacticum was introduced into these mutants, the ability to take up iron from the growth medium was restored. However, it did not mediate siderophorebiosynthesis.

If a magnetotactic bacterial strain forms colonies, the selection of non-magnetotactic mutants that do not produce magnetosomes is a relatively easy task. Generally, cells that produce magnetosomes form dark coloured, even black, colonies, whereas mutants that do not produce magnetosomes form lightercoloured, usually white to pink, colonies. Techniques for growing several magnetotactic bacterial strains including M. magneticum strain AM B-1 (REF. 59),
M . magnetotacticum ${ }^{59,108}, M$. gryphiswaldense ${ }^{108}$ and strain M V-1 (B.L. Dubbels, A.A. DiSpirito, J.D. M orton, J.D. Semrau \& D.A.B., manuscript in preparation), on the surface of agar plates have now been developed. However, when cells are grown aerobically, the oxygen concentration of the incubation atmosphere must be decreased to $0.5-2 \%$, depending on the strain. Strain M V-1 forms colonies not just microaerobically, but also anaerobically under 1 atm of $\mathrm{N}_{2} \mathrm{O}$ (B.L. Dubbels, A.A. DiSpirito, J.D. M orton, J.D. Semrau \& D.A.B., manuscript in preparation). The ability to grow cells on plates facilitates the selection of non-magnetic mutants that do not produce magnetosomes. For example, non-magnetic mutants of $M$. magneticum strain AM B-1, which were obtained following the introduction of Tn5, were easily detected using this screening technique ${ }^{109}$. Using these Tn5-derived mutants, Nakamura et al. ${ }^{74}$ found that at least three regions of the chromosome of $M$. magneticum strain AM B- 1 were required for the successful synthesis of magnetosomes. O ne of these regions, which consists of 2,975 base pairs (bp), contained two putative open reading frames, one of which, magA, was discussed above.

The presence of a cryptic 3.7-kb plasmid, pM GT, was reported in $M$. magneticum strain MGT-1 (REF. 110). Recombinant plasmids were constructed that were capable of replicating in both $M$ agnetospirillum spp. and E. coli. These plasmids could be introduced into cells using a newly developed electroporation procedure, although the authors report that cells containing magnetosomes were killed during electroporation and they therefore had to use aerobically non-magnetotactic cells.

Schultheiss and Schüler ${ }^{108}$ recently reported the development of a genetic system in M . gryphiswaldense. Colony formation on agar surfaces by this strain was achieved at a plating efficiency of $>90 \%$ by adding activated charcoal, dithiothreitol and elevated concentrations of iron compounds that were known to decompose inhibitory, toxic oxygen radicals produced during respiration in the growth medium. The cells even formed colonies (white) on agar plates that were incubated under air, although cells from these colonies werenon-magnetotactic. Protocols were also developed for the introduction of foreign DNA into cells by electroporation and high-frequency conjugation. Several broad-host-range vectors of the IncQ, IncP and $\mathrm{PBBR} 1$ groups containing antibiotic-resistance markers were shown to be capable of replicating in M. gryphiswaldense.

\section{Genomics of magnetotactic bacteria}

As a prelude to genomic studies involving magnetotactic bacteria, the genome arrangement and size of several different species were determined by pulsedfield gel electrophoresis (PFGE). The genomes of the marine vibrios, strains $M V-1$ and $M V-2$, consist of a single circular chromosome of $\sim 3.7$ and $3.6 \mathrm{M} \mathrm{b}$, respectively ${ }^{111}$. The coccus, strain M C-1, also has a single circular chromosome, of $\sim 4.5 \mathrm{M} \mathrm{b}^{111}$. There is 
no evidence for the presence of extrachromosomal DNA, such as plasmids, in these strains. The genome of $M$. magnetotacticum is arranged as a single, circular chromosome of $\sim 4.3 \mathrm{M} \mathrm{b}^{112}$.

Several magnetotactic species have recently been selected as part of a genome project in the United States, and the partially sequenced genomes of two magnetotactic bacteria, $M$. magnetotacticum and the marine coccus strain M C-1, are available for examination at the Joint Genome Institute web site (see Online Links). Schüler and co-workers have examined the organization of magnetosome membrane protein genes in M . gryphiswaldense and found that most of the mam and mms genes that encode most of the magnetosome membrane proteins are clustered within several operons ${ }^{113}$ in an unstable region of the genome that constitutes a putative magnetosome geneisland (discussed above). There are significant similarities in the conservation and organization of thesegenes in other magnetotactic bacteria, including other Magnetospirillum species and strain M C-1. However, many of these genes have not yet been shown to encodemagnetosomemembraneproteins, for example, in strain M C-1. M ost of thesefindings are summarized in a recent paper ${ }^{113}$.

\section{To the future...}

There is no doubt that the number of researchers involved in thestudy of magnetotactic bacteria has now reached a critical mass, while the subject has becomea bona fide field of research in microbiology. It is also clear that research progress in the elucidation of magnetosome synthesis has increased tremendously over the past fiveyears. We have highlighted much of this progress and its significance in this review. O wing to the numerous proteins that are present in the magnetosome membrane and the lack of information about their function, we can expect to see many studies focused on the characterization of these proteins, as well as site-directed mutagenesis studies to determine the role of these proteins in magnetite synthesis. This assumption is bolstered by the fact that several workable genetic systems are now available for many magnetotactic bacterial strains. In addition, now that we recognize the fact that many strains use siderophores for iron uptake, we can expect to see studies that examine the molecular mechanisms of iron uptake in magnetotactic bacteria and, hopefully, also studies that address one of the most important issues: why do these microorganisms take up so much iron in the first place?
1. Blakemore, R. P. Magnetotactic bacteria. Science $\mathbf{1 9 0}$ 377-379 (1975) The first report to describe the phenomenon of magnetotaxis in bacteria.

2. Balkwill, D. L., Maratea, D. \& Blakemore, R. P. Ultrastructure of a magnetic spirillum. J . Bacteriol. 141, 1399-1408 (1980). The first to describe the ultrastructural details of the magnetosome.

3. Blakemore, R. P. Magnetotactic bacteria. Annu. Rev. Microbiol. 36, 217-238 (1982)

4. Bazylinski, D. A. Structure and function of the bacterial magnetosome. ASM News 61, 337-343 (1995).

5. Moench, T. T. \& Konetzka, W. A. A novel method for the isolation and study of a magnetic bacterium. Arch. Microbiol. 119, 203-212 (1978)

6. Spring, S. \& Bazylinski, D. A. in The Prokaryotes (eds Dworkin, M. et al.) (Springer, New York, 2000) [online], (cited 14 J an 2004),

<http://141.150.157.117:8080/prokPUB/chaprender/jsp/s howchap.jsp? chapnum $=281$ \&initsec $=04 \_02>(2000)$.

7. Bazylinski, D. A. \& Blakemore, R. P. Nitrogen fixation (acetylene reduction) in Aquaspirillum magnetotacticum. Curr. Microbiol. 9, 305-308 (1983).

8. Bazylinski, D. A. \& Blakemore, R. P. Denitrification and assimilatory nitrate reduction in Aquaspirillum magnetotacticum. Appl. Environ. Microbiol. 46, 1118-1124 (1983).

9. Bazylinski, D. A., Dean, A. J ., Schüler, D., Phillips, E. J. P. \& Lovley, D. R. $\mathrm{N}_{2}$-dependent growth and nitrogenase activity in the metal-metabolizing bacteria, Geobacter and Magnetospirillum species. Environ. Microbiol. 2, 266-273 (2000)

10. Bazylinski, D. A., Frankel, R. B. \& J annasch, H. W. Anaerobic production of magnetite by a marine magnetotactic bacterium. Nature 334, 518-519 (1988). The first report of an anaerobic magnetotactic bacterium

11. Bazylinski, D. A. \& Frankel, R. B. in Environmenta Microbe-M ineral Interactions (ed. Lovley, D. R.) 109-144 (ASM Press, Washington DC, USA, 2000).

12. Cox, B. L. et al. Organization and elemental analysis of P$\mathrm{S}-$, and Fe-rich inclusions in a population of freshwater magnetococci. Geomicrobiol. J. 19, 387-406 (2002).

13. Sakaguchi, T., Burgess, J . G. \& Matsunaga, T. Magnetite formation by a sulphate-reducing bacterium. Nature 365 47-49 (1993).

14. Farina, M. Esquivel, D. M. S. \& Lins de Barros, H. G. P. Magnetic iron-sulphur crystals from a magnetotactic microorganism. Nature 343, 256-258 (1990).
15. Mann, S., Sparks, N. H. C., Frankel, R. B., Bazylinski, D. A $\& J$ annasch, H. W. Biomineralization of ferrimagnetic greigite $\left(\mathrm{Fe}_{3} \mathrm{O}_{4}\right)$ and iron pyrite $\left(\mathrm{FeS}_{2}\right)$ in a magnetotactic bacterium. Nature 343, 258-260 (1990).

References 14 and 15 represent the two original companion papers announcing the discovery of iron sulphide crystals in a magnetotactic bacterium.

16. Lowenstam, H. A. Minerals formed by organisms. Science 211, 1126-1131 (1981).

A pioneering review and evaluation of biomineralization.

17. Frankel, R. B., B lakemore, R. P. \& Wolfe, R. S. Magnetite in freshwater magnetotactic bacteria. Science $\mathbf{2 0 3}$ 1355-1356 (1979).

This pioneering paper not only describes the discovery of magnetite in bacteria but also represents the first report of metal crystals in bacteria.

18. Heywood, B. R., Bazylinski, D. A . Garratt-Reed, A. J Mann, S. \& Frankel, R. B. Controlled biosynthesis of greigite $\left(\mathrm{Fe}_{3} \mathrm{~S}_{4}\right)$ in magnetotactic bacteria. Naturwiss. 77, 536-538 (1990).

19. Pósfai, M., Buseck, P. R., Bazylinski, D. A. \& Frankel, R. B Reaction sequence of iron sulfide minerals in bacteria and their use as biomarkers. Science 280, 880-883 (1998).

20. Pósfai, M., Buseck, P. R., Bazylinski, D. A. \& Frankel, R. B. Iron sulfides from magnetotactic bacteria: structure, compositions, and phase transitions. Am. Mineral. 83 1469-1481 (1998).

21. Bazylinski, D. A., Heywood, B. R., Mann, S. \& Frankel, R. B. $\mathrm{Fe}_{3} \mathrm{O}_{4}$ and $\mathrm{Fe}_{3} \mathrm{~S}_{4}$ in a bacterium. Nature 366, 218 (1993).

22. Bazylinski, D. A. et al. Controlled biomineralization of magnetite $\left(\mathrm{Fe}_{3} \mathrm{O}_{4}\right)$ and greigite $\left(\mathrm{Fe}_{3} \mathrm{~S}_{4}\right)$ in a magnetotactic bacterium. Appl. Environ. Microbiol. 61, 3232-3239 (1995).

23. Meldrum, F. C., Heywood, B. R., Mann, S., Frankel, R. B. $\&$ Bazylinski, D. A. Electron microscopy study of magnetosomes in two cultured vibrioid magnetotactic bacteria. Proc. R. Soc. Lond. B Biol Sci. 251, 237-242 (1993).

24. Meldrum, F. C., Heywood, B. R., Mann, S., Frankel, R. B. \& Bazylinski, D. A. Electron microscopy study of magnetosomes in a cultured coccoid magnetotactic bacterium. Proc. R. Soc. Lond. B Biol. Sci. 251, 231-236 (1993).

25. Towe, K. M. \& Moench, T. T. Electron-optical characterization of bacterial magnetite. Earth Planet. Sci. Lett. 52, 213-220 (1981).
26. Arakaki, A., Webb, J \& \& Matsunaga, T. A novel protein tightly bound to bacterial magnetite particles in Magnetospirilum magneticum strain AMB-1. J . Biol. Chem. 278, 8745-8750 (2003).

Shows the drastic effect of a purified magnetosome membrane protein on the morphology of magnetite crystals produced inorganically.

27. DeLong, E. F., Frankel, R. B. \& Bazylinski, D. A. Multiple evolutionary origins of magnetotaxis in bacteria. Science 259, 803-806 (1993)

The first and only paper so far to report the phylogenetic analysis of a greigite-producing magnetotactic bacterium.

28. Woese, C. R. Bacterial evolution. Microbiol. Rev. 51 221-271 (1987).

29. Zavarzin, G. A., Stackebrandt, E. \& Murray, R. G. E. A correlation of phylogenetic diversity in the Proteobacteria with the influences of ecological forces. Can. J. Microbiol. 37, 1-6 (1991).

30. Kawaguchi, R. et al. Phylogenetic analysis of a novel sulfatereducing magnetic bacterium, RS-1, demonstrates its membership of the $\delta$-Proteobacteria. FEMS Microbiol. Lett 126, 277-282 (1995)

31. Spring, S. et al. Dominating role of an unusual magnetotactic bacterium in the microaerobic zone of a freshwater sediment. Appl. Environ. Microbiol. 59, 2397-2403 (1993).

32. Bazylinski, D. A., Garratt-Reed, A. J . \& Frankel, R. B. Electron microscopic studies of magnetosomes in magnetotactic bacteria. Microsc. Res. Tech. 27, 389-401 (1994).

33. Mann, S., Frankel, R. B. \& Blakemore, R. P. Structure, morphology and crystal growth of bacterial magnetite. Nature 310, 405-407 (1984).

34. Mann, S., Sparks, N. H. C. \& Blakemore, R. P. Ultrastructure and characterization of anisotropic inclusions in magnetotactic bacteria. Proc. R. Soc. Lond. B Biol. Sci. 231, 469-476 (1987)

35. Mann, S., Sparks, N. H. C. \& Blakemore, R. P. Structure morphology and crystal growth of anisotropic magnetite crystals in magnetotactic bacteria. Proc. R. Soc. Lond. B Biol. Sci. 231, 477-487 (1987).

36. Thornhill, R. H., Burgess, J. G., Sakaguchi, T. \& Matsunaga, T. A morphological classification of bacteria containing bulletshaped magnetic particles. FEMS Microbiol. Lett. 115 169-176 (1994).

37. Butler, R. F. \& Banerjee, S. K. Theoretical single-domain grain size range in magnetite and titanomagnetite. J. Geophys. Res. 80, 4049-4058 (1975). 
38. Diaz-Ricci, J. C. \& Kirschvink, J. L. Magnetic domain state and coercivity predictions for biogenic greigite $\left(\mathrm{Fe}_{3} \mathrm{~S}_{4}\right): a$ comparison of theory with magnetosome observations. J. Geophys. Res. 97, 17309-17315 (1992).

39. Devouard, B. et al. Magnetite from magnetotactic bacteria: size distributions and twinning. Am. Mineral. 83, 1387-1398 (1998).

40. Moskowitz, B. M., Frankel, R. B., Bazylinski, D. A J annasch, H. W. \& Lovley, D. R. A comparison of magnetite particles produced anaerobically by magnetotactic and dissimilatory iron-reducing bacteria. Geophys. Res. Lett. 16, 665-668 (1989)

41. Bazylinski, D. A. \& Moskowitz, B. M. Microbial biomineralization of magnetic iron minerals: microbiology, magnetism and environmental significance. Rev. Mineral. 35, 181-223 (1997).

42. Penninga, l., deWaard, H., Moskowitz, B. M., Bazylinski, D. A $\&$ Frankel, R. B. Remanence curves for individual magnetotactic bacteria using a pulsed magnetic field. J. Magn. Magn. Mater. 149, 279-286 (1995)

43. Proksch, R. B. et al. Magnetic force microscopy of the submicron magnetic assembly in a magnetotactic bacterium. Appl. Phys. Lett. 66, 2582-2584 (1995).

44. Dunin-Borkowski, R. E. et al. Magnetic microstructure of magnetotactic bacteria by electron holography. Science 282, 1868-1870 (1998)

Provides the best evidence that the magnetosome chain behaves as a single magnetic dipole within cells of magnetotactic bacteria.

45. Frankel, R. B. Magnetic guidance of organisms. Annu. Rev. Biophys. Bioeng. 13, 85-103 (1984).

46. Frankel, R. B., Bazylinski, D. A., J ohnson, M. \& Taylor, B. L. Magneto-aerotaxis in marine, coccoid bacteria. Biophys. J. 73, 994-1000 (1997).

Shows how magnetotaxis and aerotaxis work in conjunction in magnetite-producing magnetotactic bacteria and describes axial and polar magnetoaerotaxis.

47. Blakemore, R. P., Frankel, R. B. \& Kalmijn, A. J Southseeking magnetotactic bacteria in the southern hemisphere. Nature 236, 384-385 (1980).

48. Taylor, B. L., Zhulin, I. B. \& J ohnson, M. S. Aerotaxis and other energy-sensing behavior in bacteria. Annu. Rev. Microbiol. 53, 103-128 (1999).

49. Rogers, F. G. et al. Intercellular structure in a many-celled magnetotactic procaryote. Arch. Microbiol. 154, 18-22 (1990).

50. Bazylinski, D. A., Frankel, R. B., Garratt-Reed, A. J . \& Mann S. in Iron Biominerals (eds Frankel, R. B. \& Blakemore, R. P.) 239-255 (Plenum Press, New York, 2000).

51. Bazylinski, D. A. \& Frankel, R. B. in Biomineralization Processes of Iron and Manganese: Modern and Ancient Environments (eds Skinner, H. C. W. \& Fitzpatrick, R. W.) 147-159 (Catena, Cremlingen, Germany, 1992)

52. Bazylinski, D. A., Garratt-Reed, A. J., Abedi, A. \& Frankel, R. B. Copper association with iron sulfide magnetosomes in a magnetotactic bacterium. Arch. Microbiol. 160, 35-42 (1993).

53. Blakemore, R. P., Short, K. A., Bazylinski, D. A., Rosenblatt, C. \&Frankel, R. B. Microaerobic conditions are required for magnetite formation within Aquaspirillum magnetotacticum Geomicrobiol. J . 4, 53-71 (1985).

54. Mandernack, K. W., Bazylinski, D. A., Shanks, W. C. \& Bullen, T. D. Oxygen and iron isotope studies of magnetite produced by magnetotactic bacteria. Science $\mathbf{2 8 5}$ 1892-1896 (1999).

This study shows that magnetotactic bacteria do not fractionate iron in magnetite magnetosomes.

55. Sakaguchi, H. et al. Oxygen concentration-dependent induction of a 140-kDa protein in magnetic bacterium Magnetospirillum magnetotacticum MS-1. FEMS Microbiol. Lett. 107, 169-174 (1993).

56. Short, K. A. \& Blakemore, R. P. Periplasmic superoxide dismutases in Aquaspirillum magnetotacticum Arch. Microbiol. 152, 342-346 (1989).

57. Guerin, W. F. \& Blakemore, R. P. Redox cycling of iron supports growth and magnetite synthesis by Aquaspirillum magnetotacticum. Appl. Environ. Microbiol. 58, 1102-1109 (1992).

58. Schüler, D. \& Baeuerlein, E. Dynamics of iron uptake and $\mathrm{Fe}_{3} \mathrm{O}$ mineralization during aerobic and microaerobic growth of Magnetospirillum gryphiswaldense. J . Bacteriol. 180, 159-162 (1998).

59. Matsunaga, T., Sakaguchi, T. \& Tadokoro, F. Magnetite formation by a magnetic bacterium capable of growing aerobically. Appl. Microbiol. Biotechnol. 35, 651-655 (1991).

60. Matsunaga, T. \& Tsujimura, N. Respiratory inhibitors of a magnetic bacterium Magnetospirillum sp. AMB-1 capable of growing aerobically. Appl. Microbiol. Biotechnol. 39, 368-371 (1993).
61. Heyen, U. \& Schüler, D. Growth and magnetosome formation by microaerophilic Magnetospirillum strains in an oxygen-controlled fermentor. Appl. Microbiol. Biotechnol. 61, 536-544 (2003)

62. Neilands, J. B. A brief history of iron metabolism. Biol. Metals 4, 1-6 (1984)

63. Guerinot, M. L. Microbial iron transport. Annu. Rev. Microbiol. 48, 743-772 (1994).

64. Frankel, R. B., Papaefthymiou, G. C., Blakemore, R. P. \& $\mathrm{O}$ B Brien, W. $\mathrm{Fe}_{3} \mathrm{O}_{4}$ precipitation in magnetotactic bacteria. Biochim. Biophys. Acta 763, 147-159 (1983).

65. Paoletti, L. C. \&Blakemore, R. P. Hydroxamate production by Aquaspirillum magnetotacticum. J . Bacteriol. 167, 73-76 (1986).

66. Schüler, D. \& Baeuerlein, E. Iron-limited growth and kinetics of iron uptake in Magnetospirillum gryphiswaldense. Arch. Microbiol. 166, 301-307 (1996).

67. Nakamura, $C$. et al. Characterization of iron uptake in the magnetic bacterium Aquaspirillum sp. AMB-1. Appl. Biochem. Biotechnol. 39-40, 169-176 (1993).

68. Calugay, R. J., Miyashita, H., Okamura, Y. \& Matsunaga, T. Siderophore production by the magnetic bacterium Magnetospirillum magneticum AMB-1. FEMS Microbiol. Lett. 218, 371-375 (2003)

69. Van Ho, A., Ward, D. M. \& Kaplan, J. Transition metal transport in yeast. Annu. Rev. Microbiol. 56, 237-261 (2002).

70. Gorby, Y. A., Beveridge, T. J . \& Blakemore, R. P. Characterization of the bacterial magnetosome membrane. J. Bacteriol. 170, 834-841 (1988).

The first report of the presence of unique proteins in the magnetosome membrane and the first description of the magnetosome membrane as a lipid bilayer.

71. Kirchhausen, T. Three ways to make a vesicle. Nature Rev Mol. Cell Biol. 1, 187-198 (2000).

72. Okamura, Y., Takeyama, H. \& Matsunaga, T. A magnetosome specific GTPase from the magnetic bacterium Magnetospirillum magneticum AMB-1. J . Biol. Chem. 276, 48183-48188 (2001).

73. Handrick, R. et al. Unraveling the function of the Rhodospirillum rubrum activator of polyhydroxybutyrate (PHB) degradation: the activator is a PHB granule bound protein (phasin). J. Bacteriol. (in the press).

74. Nakamura, C., Burgess, J. G., Sode, K. \& Matsunaga, T. An iron-regulated gene, magA, encoding an iron transport protein of Magnetospirillum AMB-1. J . Biol. Chem. 270, 28392-28396 (1995).

75. Nakamura, C., Kikuchi, T., Burgess, J . G. \& Matsunaga, T. Iron-regulated expression and membrane localization of the MagA protein in Magnetospirillum sp. strain AMB-1. J. Biochem. 118, 23-27 (1995).

76. Grünberg, K., Wawer, C., Tebo, B. M. \& Schüler, D. A large gene cluster encoding several magnetosome proteins is conserved in different species of magnetotactic bacteria. Appl. Environ. Microbiol. 67, 4573-4582 (2001). This report compiles much genomic information on magnetotactic bacteria and shows that several magnetosome membrane protein genes in Magnetospirillum gryphiswaldense are conserved in a number of other magnetotactic bacteria.

77. Schübbe, S. et al. Characterization of a spontaneous nonmagnetic mutant of Magnetospirillum gryphiswaldense reveals a large deletion comprising a putative magnetosome island. J. Bacteriol. 185, 5779-5790 (2003). The first report that indicates that the genes fo magnetite magnetosome synthesis might be transferred between microorganisms by lateral gene transfer.

78. Nies, D. H. \& Silver, S. lon efflux systems involved in bacterial metal resistances. J. Ind. Microbiol. 14, 186-199 (1995).

79. Paulsen, I. T. \& Saier, M. H. J r. A novel family of ubiquitous heavy metal ion transport proteins. J. Membr. Biol. 156, 99-103 (1997).

80. Li, L. \& Kaplan, J . Characterization of two homologous yeast genes that encode mitochondrial iron transporters. J . Biol. Chem. 272, 28485-28493 (1997).

81. Li, L. \& Kaplan, J . The yeast gene MSC2, a member of the cation diffusion facilitator family, affects the cellular distribution of zinc. I. Biol. Chem 276, 5036-5043 (2001).

82. Mann, S. \& Frankel, R B. in Biomineralization: Chemical and Biochemical Perspectives (eds Mann, S., Webb, J . \& Williams, R. J. P.) 389-426 (VCH Publishers, New York, 1989).

83. Cornell, R. M. \& Schwertmann, U. The Iron Oxides: Structure, Properties, Reactions, Occurrences and Uses, 2nd Edition (Wiley, Weinheim, Germany, 2003).

84. Okuda, Y., Denda, K. \& Fukumori, Y. Cloning and sequencing of a gene encoding a new member of the tetratricopeptide protein family from magnetosomes of Magnetospirillum magnetotacticum. Gene 171, 99-102 (1996).
85. Okuda, Y. \& Fukumori, Y. Expression and characterization of a magnetosome-associated protein, TPR-containing MAM22, in Escherichia coli. FEBS Lett. 491, 169-173 (2001).

86. Hacker, J ., Blum-Oehler, G., Muhldorfer, I. \& Tschape, H. Pathogenicity islands of virulent bacteria: structure, function and impact on microbial evolution. Mol. Microbiol. 23, 1089-1097 (1997)

87. Hacker, J . \& Kaper, J . B. Pathogenicity islands and the evolution of microbes. Annu. Rev. Microbiol. 54, 641-679 (2000)

88. Hsiao, W., Wan, I., J ones, S. J \& \& Brinkman, F. S. L. IslandPath: aiding detection of genomic islands in prokaryotes. Bioinformatics 19, 418-420 (2003).

89. Matsunaga, T., Tsujimura, N., Okamura, Y. \& Takeyama, H. Cloning and characterization of a gene, $\mathrm{mps}$, encoding a protein associated with intracellular magnetic particles from Magnetospirillum sp. strain AMB-1. Biochem. Biophys. Res. Commun. 268, 932-937 (2000)

90. Wahyudi, A. T., Takeyama, H. \& Matsunaga, T. Isolation of Magnetospirillum magneticum AMB-1 mutants defective in bacterial magnetite particle synthesis by transposon mutagenesis. Appl. Biochem. Biotechnol. 91-93, 147-154 (2001)

91. Wahyudi, A. T., Takeyama, H., Okamura, Y., Fukuda, Y. \& Matsunaga, T. Characterization of aldehyde ferredoxin oxidoreductase gene defective mutant in Magnetospirillum magneticum AMB-1. Biochem. Biophys. Res. Commun. 303, 223-229 (2003).

92. Tamegai, H., Yamanaka, T. \& Fukumori, Y. Purification and properties of a 'cytochrome $a_{1}$-like' hemoprotein from a magnetotactic bacterium, Aquaspirillum magnetotacticum Biochim. Biophys. Acta 1158, 237-243 (1993).

93. O'Brien, W., Paoletti, L. C. \& Blakemore, R. P. Spectral analysis of cytochromes in Aquaspirillum magnetotacticum. Curr. Microbiol. 15, 121-127 (1987).

94. Tanimura, Y. \& Fukumori, Y. Heme-copper oxidase family structure of Magnetospirillum magnetotacticum 'cytochrome $a_{1}$-like' hemoprotein without cytochrome c oxidase activity. J. Inorg. Biochem. 82, 73-78 (2000).

95. Saiki, K., Mogi, T., Ogura, K. \& Anraku, Y. In vitro heme 0 synthesis by the cyoE gene product from Escherichia coli. J. Biol. Chem. 268, 26041-26044 (1993).

96. Iwata, S., Ostermeier, C., Ludwig, B. \& Michel, H. Structure at $2.8 \AA$ resolution of cytochrome c oxidase from Paracoccus denitrificans. Nature 376, 660-669 (1995)

97. Tamegai, H. \& Fukumori, Y. Purification, and some molecular and enzymatic features of a novel ccb-type cytochrome $c$ oxidase from a microaerobic denitrifier, Magnetospirillum magnetotacticum. FEBS Lett. 347, 22-26 (1994).

98. Yoshimatsu, K., Fujiwara, T. \& Fukumori, Y. Purification primary structure, and evolution of cytochrome c-550 from the magnetic bacterium, Magnetospirillum magnetotacticum. Arch. Microbiol. 163, 400-406 (1995).

99. Yamazaki, T., Oyanagi, H., Fujiwara, T. \& Fukumori, Y. Nitrite reductase from the magnetotactic bacterium Magnetospirillum magnetotacticum; a novel cytochrome $c d$ with $\mathrm{Fe}(\mathrm{II})$ :nitrite oxidoreductase activity. Eur. J. Biochem. 233, 665-671 (1995).

\section{First evidence for a role of an enzyme involved in} nitrogen oxide reduction in magnetite synthesis in a magnetotactic bacterium.

100. Taoka, A., Yoshimatsu, K., Kanemori, M. \& Fukumori, Y Nitrate reductase from the magnetotactic bacterium Magnetospirillum magnetotacticum MS-1: purification and sequence analysis. Can. J. Microbiol. 49, 197-206 (2003).

101. Short, K. A. \& Blakemore, R. P. Iron respiration-driven proton translocation in aerobic bacteria. J . Bacteriol. 167, 729-731 (1986)

102. Paoletti, L. C. \& Blakemore, R. P. Iron reduction by Aquaspirillum magnetotacticum. Curr. Microbiol. 17 339-342 (1988).

103. Noguchi, Y., Fujiwara, T., Yoshimatsu, K. \& Fukumori, Y. Iron reductase for magnetite synthesis in the magnetotactic bacterium Magnetospirillum magnetotacticum. J . Bacteriol. 181, 2142-2147 (1999).

104. Waleh, N. S. Functional expression of Aquaspirillum magnetotacticum genes in Escherichia coli K12. Mol. Gen. Genet. 214, 592-594 (1988).

105. Berson, A. E., Peters, M. R. \& Waleh, N. S. Cloning and characterization of the recA gene of Aquaspirillum magnetotacticum. Arch. Microbiol. 152, 567-571 (1989).

106. Berson, A. E., Peters, M. R. \& Waleh, N. S. Nucleotide sequence of recA gene of Aquaspirillum magnetotacticum. Nucleic Acids Res. 18, 675 (1990)

107. Berson, A. E., Hudson, D. V. \& Waleh, N. S. Cloning of a sequence of Aquaspirillum magnetotacticum that complements the aroD gene of Escherichia coli. Mol. Microbiol. 5, 2261-2264 (1991)

108. Schultheiss, D. \& Schüler, D. Development of a genetic system for Magnetospirillum gryphiswaldense. Arch. Microbiol. 179, 89-94 (2003). 
109. Matsunaga, T., Nakamura, C., Burgess, J . G. \& Sode, K Gene transfer in magnetic bacteria: transposon mutagenesis and cloning of genomic DNA fragments required for magnetite synthesis. J. Bacteriol. 174 2748-2753 (1992)

110. Okamura, Y. et al. Design and application of a new crypticplasmid-based shuttle vector for Magnetospirillum magneticum. Appl. Environ. Microbiol. 69, 4274-4277 (2003)

111. Dean, A. J . \& Bazylinski, D. A. Genome analysis of several magnetotactic bacterial strains using pulsed-field gel electrophoresis. Curr. Microbiol. 39, 219-225 (1999).

112. Bertani, L. E., Weko, J., Phillips, K. V., Gray, R. F. \& Kirschvink, J . L. Physical and genetic characterization of the genome of Magnetospirillum magnetotacticum strain MS-1. Gene 264, 257-263 (2001).

113. Schüler, D. Molecular analysis of a subcellular compartment: the magnetosome membrane in Magnetospirillum gryphiswaldense. Arch. Microbiol. 181, 1-7 (2004).

114. Palache, C., Berman, H. \& Frondel, C. Dana's System of Mineralogy Vol. 1 (Wiley, New York, 1944).

115. Chang, S.-B. R. \& Kirschvink, J. L. Magnetofossils, the magnetization of sediments, and the evolution of magnetite biomineralization. Annu. Rev. Earth Planet. Sci. 17, 169-195 (1989).

116. Stolz, J. F., Chang, S.-B. R. \& Kirschvink, J . L. Magnetotactic bacteria and single domain magnetite in hemipelagic sediments. Nature 321, 849-850 (1986).

117. Stolz, J. F., Lovley, D. R. \& Haggerty, S. E. Biogenic magnetite and the magnetization of sediments. J . Geophys. Res. 95, 4355-4361 (1990).

118. McKay, D. S. et al. Search for past life on Mars: possible relic biogenic activity in Martian meteorite ALH84001. Science 273, 924-930 (1996)

This paper provides several lines of evidence based on geological and chemical aspects of Martian meteorite ALH84001 that indicate that life existed on ancient Mars.

119. Thomas-Keprta, K. L. et al. Elongated prismatic magnetite $\left(\mathrm{Fe}_{3} \mathrm{O}\right.$, crystals in ALH84001 carbonate globules: potential Martian magnetofossils. Geochim. Cosmochim. Acta 64, 4049-4081 (2000).

120. Thomas-Keprta, K. L. et al. Truncated hexa-octahedral magnetite crystals in ALH84001: presumptive biosignatures. Proc. Natl Acad. Sci. USA 98, 2164-2169 (2001).
121. Thomas-Keprta, K. L. et al. Magnetofossils from ancient Mars: a robust biosignature in the Martian meteorite ALH84001. Appl. Environ. Microbiol. 68, 3663-3672 (2002).

122. Golden, D. C., Ming, D. W., Schwandt, C. S., Lauer, H. V. \& Socki, R. A. A simple inorganic process for formation of carbonates, magnetite, and sulfides in Martian meteorite ALH84001. Amer. Mineral. 8, 370-375 (2001).

123. Neilands, J . B. Siderophores: structure and function of microbial iron transport compounds. J. Biol. Chem. 270, 26723-26726 (1995).

124. Neilands, J. B. et al. in Iron Transport in Microbes, Plants and Animals (eds Winkelmann, G., van der Helm, D. \& Neilands, J. B.) 3-33 (VCH Press, Weinheim, Germany, 1987).

125. Braun, V. \& Hantke, K. in Transition Metals in Microbial Metabolism (eds Winkelmann, G. \& Carrano, C. J .) 81-101 (Harwood, Amsterdam, 1997).

126. Franchini, M., Gandini, G. \& Aprili, G. Advances in iron chelating therapy. Haematologica 85, 1122-1125 (2000).

127. Stintzi, A., Barnes, C. Xu, J \& Raymond, K. N. Microbial iron transport via a siderophore shuttle: a membrane ion transport paradigm. Proc. Natl Acad. Sci. USA 97 10691-10696 (2000).

128. Das, A. K., Cohen, P. T. W. \& Barford, D. The structure of the tetratricopeptide repeats of protein phosphatase 5 : implications for TPR-mediated protein-protein interactions. EMBO J. 17, 1192-1199 (1998).

129. Sikorski, R. S. et al. TPR proteins as essential components of the yeast cell cycle. Cold Spring Harb. Symp. Quant. Biol. 56, 663-673 (1991).

130. Lamb, J. R., Tugendreich, S. \& Hieter, P. Tetratricopeptide repeat interactions: to TPR or not to TPR? Trends Biochem. Sci. 20, 257-259 (1995).

131. D'Andrea, L. D. \& Regan, L. TPR proteins: the versatile helix Trends Biochem. Sci. 28, 665-662 (2003).

132. Ponting, C. P. \& Phillips, C. Rapsyn's knobs and holes: eight tetratricopeptide repeats. Biochem. J . 314, 1053-1056 (1996).

133. Lipinska, B., Fayet, O., Baird, L. \& Georgopoulos, C. Identification, characterization, and mapping of the Escherichia coli htrA gene, whose product is essential for bacterial growth only at elevated temperatures. J . Bacteriol. 171, 1574-1584 (1989).
134. Pallen, M. J \& W Wren, B. W. The HtrA family of serine proteases. Mol. Microbiol. 26, 209-221 (1997)

135. Fanning, A. S. \&Anderson, J. M. Protein-protein interactions: PDZ network domains. Curr. Biol. 6 1385-1388 (1996).

Acknowledgements

We acknowledge our students, postdoctoral researchers and numerous collaborators, and are particularly grateful for the support of the US National Science Foundation and the National Aeronautics and Space Administration. We thank Y. Fukumori for valuable discussions and suggestions; T. Matsunaga and Y. Okamura for the use of Figure 7; and D. Moyles and T. J. Beveridge for superb electron microscopy. 